\title{
ESTUDIOS
}

\section{El Campo de las Literaturas Indígenas Latinoamericanas}

Para nuestros actuales propósitos América Latina es el área que se extiende al sur de Estados Unidos incluyendo las islas del Caribe. ${ }^{1}$ Por otra parte entendemos por indios a los habitantes nativos de las Américas y sus descendientes siempre que conserven por lo menos algunas pautas y rasgos heredados o desarrollados desde la época precolombina. ${ }^{2}$ Por último, definimos a la literatura como una colección de composiciones registradas consistentes en palabras significativas. ${ }^{3}$

El campo de las literaturas indigenas latinoamericanas abarca las siguientes áreas: prehispánica, colonial indígena temprana, colonial hispánica temprana, colonial indỉgena tardia, indígena moderna, folklore indígena contemporáneo, y literatura indigenista hispanoamericana contemporánea. 4 Estas áreas incluyen documentos indígenas conservados en su lengua original, tempranos informes europeos acerca de tradiciones literarias indígenas, literatura popular moderna de América Latina influída por tradiciones indígenas, y literatura hispanoamericana contemporánea que recrea visiones del mundo americano aborigen. Otras áreas modernas de estudio científico relacionadas estrechamente con las literaturas indígenas y sus antecedentes sociales podrian agregarse: ensayos modernos sobre aspectos de las culturas indígenas, particularmente sus lenguas, literatura, simbolismo, arte, religión y pensamiento; ensayos de arqueología, etnografía, etnología, etnohistoria y antropología aplicada.

\section{Literaturas prehispánicas}

Hay dos fuentes principales de las literaturas precolombinas antiguas: los códices mesoamericanos y las inscripciones epigráficas mesoamericanas. 
Los códices o tiras plegadas de piel de venado pintada o de un material similar al papel, preparado de la corteza del amate, árbol que da un fruto parecido al higo, generalmente tenian tapas de madera entre las cuales podian guardarse las páginas dobladas. ${ }^{5}$ Los códices han sido clasificados de acuerdo a los periodos históricos a los cuales pertenecen como prehispánicos o posthispánicos. Esta última denominación puede ser reemplazada por la de "colonial temprano."6 A veces estos códices tienen notas aclaratorias en español y muestran mayor o menor divergencia con respecto a las tradiciones pictóricas prehispánicas. ${ }^{7}$ Aunque el lugar de origen de muchos códices es aún objeto de conjetura y en muchos casos probablemente seguirá siéndolo, sabemos que los tres códices mayas existentes provienen de Yucatán. 8 Otros han sido atribuidos a los actuales estados de Oaxaca, Puebla, Tlaxcala y Morelos; pero no hay duda de que libros antiguos de este tipo se usaron en toda Mesoamérica desde el Norte de México hasta Costa Rica. ${ }^{9} \mathrm{De}$ acuerdo con su contenido, los códices pueden agruparse principalmente como astronómicos, rituales, mitológicos, genealógicos, históricos y tributarios. Muchos códices caen simultaneamente bajo las tres primeras categorias y los restantes rara vez están libres de connotaciones cosmológicas. ${ }^{10} \mathrm{Se}$ ha perdido el arte de leer los códices porque se usaban más bien como auxiliares de la memoria que como textos que tienen que ser repetidos literalmente. Ello no obstante, el contenido matemático, y por tanto el significado calendárico y cronológico de la mayor parte de los códices, ha sido descifrado. 11 El estudio de los códices mesoamericanos constituye un tema fascinante, realzado por la belleza poco cumún de las pinturas precolombinas y su influencia posterior. ${ }^{12} \mathrm{~A}$ pesar de las obvias dificultades del simbolismo antiguo, han habido grandes progresos en la interpretación de estos documentos únicos. ${ }^{13}$ Muchos códices se conservan en bibliotecas europeas donde, a veces, han sido confundidos con antigüedades egipcias o chinas. El Museo Nacional de Antropologìa de la ciudad de México conserva más de una docena de códices, casi todos de los comienzos de la época colonial. En Estados Unidos hay códices originales mexicanos en la biblioteca de la Universidad de Tulane (New Orleans), en el Museo de Historia Natural en New York, y otras partes. 14

Además del texto jeroglífico pintado en algunos de los códices, hay un considerable cuerpo de inscripciones en estelas, altares, edificios, juegos de pelota, y aún en pequeños objetos de jade, piedra dura, hueso, concha, metal, y en cerámica pintada o cincelada y moldeada. La mayoria de estas fuentes se ha encontrado en el área maya. 
Es probable que ocurran más descubrimientos de esta naturaleza. ${ }^{15}$ Antes se pensaba que los textos jeroglíficos registraban temas impersonales, como fechas calendáricas y ceremonias religiosas, pero se ha sostenido en forma plausible que también pueden señalar sucesos históricos y hechos biográficos, como la ascensión de un gobernante al poder. ${ }^{16}$ A pesar de la importancia de esta clase de escritura para nuestro conocimiento de las matemáticas, astronomía, astrología, $\mathrm{y}$ tal vez historia y genealogía mesoamericanas, particularmente maya, no hay prueba de que fuera usada para registrar literatura. Como otras grandes civilizaciones de la antigüedad, la literatura mesoamericana fue originalmente oral. ${ }^{17} \mathrm{~A}$ fin de apreciarla debemos recurrir a textos tradicionales que fueron fijados cuando se estableció la costumbre europea de poner la literatura por escrito.

\section{Primeras literaturas coloniales indias}

Algunos de los documentos de las literaturas indígenas del temprano colonial se limitan a continuar tradiciones precolombinas, como ciertos códices y mapas que muestran escritura jeroglífica y, a veces, notas en español añadidas por diversos autores. ${ }^{18} \mathrm{La}$ introducción del alfabeto romano y la importancia dada por los españoles a la palabra escrita hicieron que los antiguos libros pintados cayeran gradualmente en desuso. Las tradiciones orales fueron reemplazadas por breves textos y explicaciones, algo más extensas, de las figuras. Con el tiempo las figuras de color se convirtieron solamente en ilustraciones y adornos. Su estilo se deterioró: el choque de técnicas artǐsticas produjo ejemplares hibridos de poco mérito. ${ }^{19}$ Por otra parte, algunos escritores indígenas que habian aprendido a usar el alfabeto romano poco después de la conquista comenzaron a escribir tradiciones náhuatles en escritura romana. 20 Posteriores generaciones de mestizos continuaron haciéndolo. Algunos de los primeros trabajos son sólamente descripciones de antiguos libros pintados con pequeños comentarios añadidos. Ocasionalmente, el mismo escritor náhuatl adoptó el español y produjo una obra literaria que es al mismo tiempo española e indǐgena. 21

Se da también el caso del escritor español que aprendió la lengua de los indios y trató de expresar lo mejor que pudo sus mitos, leyendas y cultos. Uno de los primeros intentos de recopilar las literaturas orales y religiones nativas fue encomendado por el mismo Colón $y$ ha producido el primer ensayo etnográfico de las Américas. 22 
Como ocurre con las tradiciones orales en general, muchas obras de la literatura indígena colonial son anónimas. ${ }^{23} \mathrm{Hay}$, sin embargo, todo un cuerpo de esa literatura que merece mención especial por la riqueza de materiales incluídos y por el excelente método empleado para obtener la información. Este fue el trabajo de Bernardino de Sahagún (1500-1590), franciscano español que llegó a dominar la lengua náhuatl, formó discípulos, y tuvo la colaboración de informantes nativos que sabỉan escribir náhuatl, latín y español. Su obra literaria se realizó en varios colegios cerca de México Tenochtitlán, la mayor parte de ella en Santa Cruz de Tlatelolco, entre 1547 y 1580.24 Sahagún ha sido considerado como pionero en la investigación etnográfica moderna. Sus recopilaciones en náhuatl, con una versión española que es en realidad un comentario corrido, son una mina de datos sobre la vida, pensamiento y literatura azteca. Como los poemas, cantos y mitos náhuatles sin duda provenían de antiguas tradiciones, los códices de Sahagún pueden considerarse como fuentes de corrientes literarias que llegaron a México Tenochtitlán a través de culturas más antiguas, especialmente las de Tula y Teotihuacán.

De las culturas del Golfo de México, que en la época de la conquista española habian alcanzado muy alto nivel de civilización, no quedan documentos literarios del período colonial temprano. Lo mismo puede decirse del área maya de Yucatán, Chiapas y Guatemala, con la excepción de la obra de Diego de Landa (1524-1572), fraile franciscano que habiéndose distinguido por quemar un gran número de códices mayas, luego en España a propósito de un proceso legal redactó un notable informe sobre la civilización que tan vigorosamente contribuyó a desarraigar. 25

En los paises andinos quedan, empobrecidas, literaturas orales que han sobrevivido hasta nuestros días, la mayor parte en lengua quechua. Hay también varios testimonios indígenas importantes, principalmente de obras históricas compuestas en el siglo XVI por indios y mestizos que conocian el quechua y el español pero que escribieron en la lengua de los conquistadores, 26 a veces con mucho éxito, como el humanista clásico Garcilaso de la Vega (1539-1616), 27 a veces en una extraña mezcla de quechua y español como la obra única del escritor y artista Guamán Poma de Ayala (1534? - después 1613).28 Otros valiosos documentos andinos acerca de las literaturas indigenas provienen del celo de sacerdotes que, como Landa en Yucatán, realizaron investigaciones de campo con el objeto de conocer mejor la religión que querían erradicar. El 
más valioso de estos textos procede del mestizo jesuita Francisco de Avila (1573-1647) cuyo pequeño libro acerca de las creencias y prácticas de los indios de Huarochirí nos introduce en antiguas tradiciones mitológicas. 29

\section{Literatura española de principios de la época colonial}

Acabamos de mencionar algunos escritores de principios de la época colonial que dejaron valiosos testimonios acerca de las antiguas literaturas indígenas, en español, en las lenguas aborígenes, o en las dos. Entre ellos habian indios, mestizos y algunos españoles que recogieron tradiciones nativas. Aunque la intención primordial de otros escritores españoles, principalmente exploradores y conquistadores, no era la de contar los cantos y cuentos de los indios, a través de sus cartas, informes y otros documentos oficiales incluyeron relatos de primera mano o información bien comprobada acerca de formas de vida, creencias, y a veces sobre mitos y leyendas indigenas. En el campo de la literatura del descubrimiento y la conquista -capitulo fascinante de la literatura de viajes - la contribución española no es inferior a ninguna otra; sólo puede comparársele la obra contemporánea de algunos navegantes portugueses. 30 Fue inaugurada por Colón con sus cartas, donde describió por primera vez las poblaciones que encontró en las Indias Occidentales, 31 dando lugar a estereotipos contradictorios: la visión de que los pobladores del nuevo mundo son naturalmente buenos (la idea del buen salvaje), y la idea de que eran implacables caníbales (la idea de inferioridad moral). Estas visiones fueron responsables de muchos ensayos literarios y políticos de la edad moderna. 32 Igualmente clásicos son los informes de primera mano de la conquista de México escritos por Hernán Cortés 33 y Bernal Díaz del Castillo. ${ }^{34}$ En vívidas páginas que han sido citadas muchas veces, ambos escritores reflejaron la magnífica vista de la intacta Tenochtitlán ante los asombrados ojos de los españoles que avanzaban, un pequeño ejército sostenido por un considerable número de aliados tlaxcaltecas. Esta hermosa vista ha inspirado también a modernos escritores. 35

La exploración de diferentes regiones de Sud América es también rica en deliciosas narraciones de aventuras que incluyen memorables pasajes sobre sociedades primitivas, 36 encuentros con amazonas aborìgenes, ${ }^{37}$ la brillante civilización de los Andes, ${ }^{38}$ y los indómitos guerreros de Chile aprendiendo rápidamente las tácticas de sus invasores y repeliendo el ataque con legendaria inteligencia y coraje. 39 
Además de las obras de los exploradores y conquistadores que relatan sus osadas hazañas tenemos también algunos notables ensayos de historiografía americana escritos en la primera parte de la época colonial. Algunos fueron intentados por españoles que poseìan considerable experiencia de las Indias, ${ }^{4} 0$ otros nunca habǐan dejado España pero fundaron sus escritos en conversaciones con testigos, o colecciones de cartas, informes y otros documentos sin par (muchos de los cuales se han perdido) de los primeros viajeros a las Américas. 41 Todos son pertinentes para un estudio comprehensivo de las culturas y tradiciones indigenas en los comienzos del período colonial. 42

\section{Literaturas indigenas de la época colonial posterior}

La literatura indiggena de principios de la época colonial consistía en su mayor parte de textos sobre antiguas tradiciones, desde composiciones poéticas y mitos cosmogónicos a historias tribales, que a veces llevan el tema hasta entrada la época colonial. En el curso del siglo XVI escritores nativos comenzaron a usar caracteres romanos para relatar en sus propias lenguas aborigenes viejas leyendas, memorias históricas, hechos corrientes, y muchas otras informaciones que, en algunos casos, a través de sucesivas copias fueron transmitidos a generaciones posteriores. Mientras la temprana literatura indígena colonial ponía el acento en el pasado precolombino, los esfuerzos literarios del periodo colonial posterior se concentran en las creencias, prácticas y hechos de la vida de la comunidad indỉgena contemporánea en una circunstancia española y cristiana. Con algunas inevitables repeticiones, una primera clasificación de estos documentos podría poner a la mayoría de ellos bajo las categorías de anales, títulos de tierras y cuadernos de apuntes diversos.

El libro hoy llamado comúnmente Los anales de los Cakchiqueles, pieza incomparable de la literatura indigena, fué comenzado probablemente poco después de la conquista de Guatemala por los españoles. 43 Lo inició un miembro de la familia Xahil, y lo continuaron otras personas de la misma área del Lago Atitlán. Da una breve narración mítica acerca del origen del hombre, que reproduce probablemente muy antiguas tradiciones orales, cuenta la historia de reyes y guerreros cakchiqueles así como algunos aspectos de la conquista española. Siguiendo la secuencia cronológica fijada en el calendario maya, la historia continúa hasta el año 1604. Esta notable obra trata de nacimientos y muertes, litigios acerca de la tenencia de tierras, eclipses y terremotos, gastos generales, mejoras en la iglesia y 
mucho más, lo que hace de ella uno de los más valiosos libros de fuentes para el estudio de la vida social en la villa indígena de Sololá durante el siglo XVI.

De otras áreas de Guatemala tenemos también varias obras cortas, principalmente referentes a derechos de tierras, que incluyen información preciosa sobre la historia temprana de los quiché. El más largo y quizás el más importante entre estos breves textos es el Título de los Señores de Totonicapán (la vieja villa de Chimekenhá), donde leemos acerca de los legendarios orĭgenes del pueblo quiché y su historia hasta llegar a los tiempos de su rey Quitab. Fue escrito alrededor de 1554.44 Crónicas de los quiché, aún más cortas, se han conservado en antiguos manuscritos o copias posteriores que proporcionaron útiles resúmenes de la historia quiché en los siglos XVI, XVII y XVIII. 45

La obra más famosa de la literatura quiché es sin duda el Popol Vuh, libro que contiene el más rico relato de la mitología maya, como también un resumen de la historia y de la genealogìa quiché hasta la llegada de los españoles. En el comienzo del volumen el autor manifiesta que el Popol Vuh original no existe, y que él está escribiendo bajo un nuevo régimen. Al final repite que el viejo libro poseîdo por los reyes ha desaparecido. Esto ha llevado a suponer que existió un antiguo códice donde las historias del Popol Vuh estaban pintadas y que el autor anónimo las relata de memoria. De cualquier modo, la mayor parte del Popol $V u h$ es pura mitologia y debe ser leĭda como tal. Coincidencias con historias bíblicas, como por ejemplo la destrucción del mundo por el agua, no indican necesariamente influencias cristianas porque el Diluvio es un motivo universal particularmente bien conocido entre los pueblos indígenas de las Américas. 47

El área maya de Yucatán conservaba hasta hace comparativamente poco tiempo una cantidad de manuscritos comunales que ahora suelen llamarse Libros del Chilam Balam (o del sacerdote Jaguar), según el nombre de un célebre sacerdote precolombino que vivió en la ciudad de Mani. El contenido de estos libros es variado; consiste en textos religiosos (mayas o cristianos), históricos (siguiendo el calendario maya o simplemente registrando minucias), relativos a la medicina (maya tradicional o influída por los europeos), astronómicos y astrológicos (incluyendo explicaciones del calendario maya y referencias a la astronomia europea), ritual, literarios (incluyendo novelas españolas), y otros textos que no han sido clasificados. A pesar de que los manuscritos originales fueron escritos poco después de la conquista española, muchos de ellos han llegado a noso- 
tros en copias que muestran haber sido usados durante todo el periodo colonial y aún después. Todos están escritos en maya yucateco usando caracteres romanos. 48

El drama precolombino perduró en el área quiché de Guatemala a lo largo del periodo colonial, como lo atestigua el Rabinal Achi' o Danza del Tun, que se seguía representando en el siglo XIX.49 Otros ejemplos importantes del drama indïgena colonial, aunque teñido de influencias hispánicas, son el Güegüence náhuat ${ }^{50}$ de Nicaragua y el Ollantay ${ }^{1}$ quechua de Perú.

\section{Literaturas indigenas modernas}

Como acabamos de ver, algunas tradiciones literarias indigenas sobrevivieron a través del periodo colonial, aunque la presencia de una poderosa civilización cristiana se refleja a menudo en los textos registrados. Esto es bastante natural, especialmente porque una condición para poder fijar textos aborígenes era la existencia de indígenas, aculturados al menos parcialmente, capaces de usar el alfabeto romano. Sin embargo, los textos nativos escritos durante el período colonial no deben ocultarnos el hecho de que la literatura indígena de todos los tiempos es primariamente oral. Esto se percibe más claramente cuando dejamos las áreas de alta civilización, que fueron prontamente ocupadas por los españoles en Mesoamérica y los Andes Centrales, y enfocamos nuestra atención en las culturas tribales que vivieron con pequeño o ningún contacto con europeos a través del periodo colonial y a veces aún hasta en el siglo XX. Debido a la escasez de información acerca de muchas tribus durante el período colonial, no podemos establecer la naturaleza de sus literaturas orales antes del siglo XIX, pero, en cambio, las investigaciones científicas modernas realizadas por lingüistas y otros competentes investigadores de campo han producido un tesoro de textos indígenas que supera todo lo que tenemos de otros períodos de la historia de América Latina. Como sus sociedades indígenas son cada vez más desorganizadas por la interferencia de los blancos, algunos indios han llegado a comprender cuán importante puede ser conservar por escrito sus literaturas para la continuidad cultural de sus tribus. Donde la mayoría se oponia a revelar las tradiciones orales sagradas, ahora es frecuente encontrar informantes voluntarios dispuestos a grabar y ayudar a traducir y transcribir sus tradiciones orales. 52

El número de libros, monografías y artïculos con transcripciones y/o traducciones de las literaturas orales indígenas desde el siglo XIX es simplemente abrumador, y continúa aumentando. 53 En muchos 
casos es el resultado de la colaboración entre un informante aborigen particularmente talentoso y un lingüista occidental. ${ }^{54}$ En otros casos el informante es suficientemente versado en español o portugués para dictar sus textos en su segunda lengua. Por supuesto este procedimiento no puede usarse para registrar poesīa. Aún otras formas de literatura oral sufren, como es de entender, por la imposibilidad de transmitir en una lengua prestada matices de significación que sólo pueden expresarse en el idioma nativo. La importancia de esta dificultad, no obstante, no debe exagerarse, porque muchas imágenes desusadas y giros de pensamiento pueden ser comunicados en la lengua adquirida tardî́amente. Además hay versiones, en lenguas europeas modernas, de tradiciones indígenas recogidas por escrito por estudiosos que no son especialistas en lenguas indiggenas (o por lo menos no en todas aquellas cuya literatura están manejando), pero que han basado su trabajo en textos proporcionados por buenos investigadores y a menudo acompañados por traducciones literales, versiones a otras lenguas modernas, y otros recursos auxiliares. 55

Los materiales disponibles para el estudio de las modernas literaturas indígenas consisten en su mayor parte en mitos, leyendas, cantos, poemas, discursos y proverbios. 56 Por supuesto no todos estos géneros pueden encontrarse en una sola tribu, o acaso no poseemos la documentación apropiada. La producción más abundante de las literaturas indígenas procede de las mitologías de las sociedades aborïgenes sudamericanas. 57

\section{Literaturas folklóricas indigenas modernas}

El mestizaje cultural, que ha sido un proceso continuo en la mayorïa de las regiones de Latinoamérica desde principios de la época colonial, se ha acelerado en los tiempos modernos. Culturas mestizas son el resultado natural de este cambio continuo. En muchas regiones donde corrientemente se habla el español o portugués, y las antiguas pautas sociales y políticas pueden haber sido alteradas hasta lo irreconocible, hay, sin embargo, un sustrato subyacente de creencias y simbolos indígenas que tienen origen en la mitología e imaginería precolombinas. 58 Debe admitirse que estos elementos están a menudo fundidos con otros de procedencia europea, pero la fusión ocurre tan naturalmente en la mente aborigen como la simultánea presencia de un santo cristiano y un ídolo pagano en un santuario indígena. 59 No es raro que el nombre y la figura de un símbolo sagrado cristiano reemplace el nombre y la figura de un 
viejo dios o diosa indígenas, pero no sus atributos. La esencia de la cuestión reside en la capacidad de los antiguos modos de pensamiento para mantener su bien establecida coherencia a pesar de presiones que quieren obligarlo a usar nuevas palabras e imágenes simbólicas, presiones que generalmente lo llevan a conformarse a las circunstancias políticas a fin de sobrevivir. Si bien no es fácil determinar en cada caso hasta qué punto ha llegado esta adaptación, es evidente que, con la posible excepción de centros extremadamente cosmopolitas, gran número de rasgos fundamentales de la antigua cosmovisión del mundo indígena subyace en las modernas culturas mestizas de América Latina. 60

Los elementos y estructuras indïgenas que se encuentran en las literaturas orales de las sociedades mestizas han sido estudiados, recogidos y recreados por ciertos escritores modernos de Latinoamérica. Algunos han tratado de recuperar las palabras mismas de los hablantes mestizos o de los indios de habla española tal como son verdaderamente pronunciadas. 61 Otros se toman la libertad de refundirlas en un lenguaje que consideran más gramatical, pulido o elegante. 62 Como los escritores se dan cuenta de que el habla popular tiene sus propios valores, el primer camino es preferible, pero es muy tenue el límite que separa el arte de editar las expresiones espontáneas de una cultura mestiza y el campo de la literatura de creación. Aún donde no hay modo de descubrir lo que es simplemente tomado de lo que es totalmente refundido, hay sin duda un animado componente aborigen en la obra acabada de los modernos escritores americanos del folklore indïgena.

Las modernas literaturas folklóricas indígenas se han desarrollado principalmente en paises donde el proceso de aculturación ha ocurrido a lo largo de centurias. Ya no es así. A medida que indígenas de remotas regiones selváticas, boscosas o desérticas son gradualmente invadidos por la civilización europea, surgen nuevas culturas mestizas. Las literaturas de estos mestizos probablemente reemplazarán en español las tradiciones indígenas más o menos puras que todavía pueden escucharse en las lenguas vernáculas. En estas nuevas formas de cruce cultural no siempre son los santos cristianos y las autoridades políticas blancas las que reemplazan sus equivalentes indiggenas en las pautas de pensamiento aborigen sino más bien medicinas modernas como la aspirina y artefactos como machetes de acero, motores fuera de borda, y radios a transistores. Pero la vieja magia tal vez aún reside en ellos. 


\section{Literatura indigenista hispanoamericana moderna}

Mientras las modernas literaturas indígenas reflejan las tradiciones aborígenes tales como las cuentan los pueblos nativos, y la moderna literatura folklórica indiggena presenta las composiciones orales de las comunidades mestizas en un español que incluye muchas palabras y expresiones indígenas, la literatura "indigenista" hispanoamericana moderna es el resultado del esfuerzo deliberado de autores modernos, impregnados de tradiciones europeas y literatura hispanoamericana, para presentar en español algunos aspectos de la vida indígena que enriquezcan nuestra visión del mundo. Estos esfuerzos pueden tener razones estéticas, morales, políticas, filosóficas, u otras. Se han escrito obras de esta clase en prosa y en verso. De las obras en prosa, la novela y el cuento han sido los géneros favoritos. El ensayo "indigenista" es otra notable forma literaria.

Es conveniente establecer una diferencia entre "indianista" e "indigenista." Por "indianista" significamos aquellas creaciones literarias de escritores hispanoamericanos que presentan caracteres y temas indígenas como elementos exóticos en composiciones literarias que de otro modo son totalmente europeas en su enfoque y estilo. El indio puede ser objeto de sincera compasión, un buen salvaje que debe ser protegido de las crueldades de los blancos, un ser profundamente humano a pesar de sus rasgos físicos y costumbres no europeos, pero la literatura "indianista" no proporciona ninguna contribución significativa para nuestro conocimiento de las culturas indĭgenas ni es afectada básicamente por el tema indïgena. Este fue por lo común el modo de tratar temas indígenas en las novelas del siglo XIX. Por otra parte, la literatura "indigenista" se esfuerza por introducir las caracterǐsticas de la existencia y experiencia aborĭgenes en creaciones literarias hispanoamericanas. Esta corriente comenzó describiendo con cierta extensión la conducta y atmósfera social de los indios e incorporando libremente cierta cantidad de frases nativas al texto español de la narrativa. Aunque más fiel a la realidad que el enfoque "indianista," era todavìa un recurso mecánico. La formación etnográfica y lingüîstica del escritor puede haber sido buena, y al lector se le ofrecía una imagen más segura de los aborígenes, pero éstos todavía seguían siendo vistos desde fuera. Ahora el movimiento literario "indigenista" ha hecho nuevos progresos. Ha sabido alcanzar técnicas más refinadas para tratar la experiencia de la vida indígena. Escritores como Miguel Angel Asturias, José Marỉa Arguedas y Rosario Castellanos han transformado con éxito las convenciones 
literarias para abordar la cosmovisión indígena. 65 Han creado una nueva lengua, una nueva imaginería y una nueva técnica usando insólitos puntos de vista, modos de pensamiento, mitos y leyendas que iluminan la vida espiritual indïgena desde dentro. El lector es invitado a participar en una nueva especie de experiencia vital, a someterse a cierta forma de iniciación. El resultado final no es ni puramente hispanoamericano convencional ni indio. El primero dejaría afuera la visión esencialmente indigena; el segundo seria ininteligible para los lectores de español. Es un nuevo lenguaje y modelo estético inventado por el escritor para lograr una nueva realización poética ontológica. Por medio de ella podemos tener acceso a una realidad que va más allá de la vida cotidiana y las formas convencionales de la literatura americana. No es ya una imagen indígena selecta, más o menos afortunadamente introducida en una composición, sino una revelación del espíritu indïgena mediante la transformación consciente de pautas literarias europeas por escritores que en su mayor parte fueron educados con modelos estéticos occidentales.

Paralelamente con estos desarrollos en la ficción, el ensayo indigenista ha tomado dos principales líneas de ataque. Una de ellas puede caracterizarse brevemente como reflexiones acerca de la vida y cultura indígena con referencia a su progreso social y económico. A los indios, se dice, debería dárseles plena oportunidad de convertirse en miembros del mundo moderno occidentalizado. La otra es más bien un esfuerzo intelectual por comprender la vida y valores indígenas basado en la creencia de que las formas de vida y pensamiento indiggenas pueden enseñarnos a mirar el mundo como quizás alguna vez lo hicimos, pero que ahora hemos olvidado completamente. La primera clase de ensayos recomienda ayudar a los indios a obtener un progreso social tal como nosotros lo entendemos. ${ }^{66} \mathrm{La}$ segunda desea beber en fuentes indigenas para nuestro propio progreso espiritual.67 Una demanda más democracia y tecnología para los indios; la otra explora las costumbres, pensamiento y expresión indígenas con la esperanza de que perennes visiones nativas renueven nuestra casi agotada sabidurì. Estas dos concepciones no son necesariamente contradictorias. Debido a la diversidad de la situación social y económica de los diferentes grupos de indios, y la gran divergencia en el grado de aculturación o desintegración de varias sociedades nativas, es posible sostener puntos de vista diferentes acerca de lo que es mejor para una comunidad indígena y la conveniencia de preservar modos tradicionales de pensamiento y conducta. Estas concepciones dependerán en gran medida del estado actual de la particular tribu o nación indïgena a que nos refiramos. 


\section{Observaciones finales}

Las páginas precedentes han tratado de bosquejar el campo de las literaturàs indiggenas de América Latina tal como las entendemos hoy. Para terminar este breve ensayo quisiéramos subrayar algunos puntos.

1. Las literaturas indigenas han sido siempre primariamente orales. Esto es verdad aún para aquellas culturas que han tenido medios de fijar sus pensamientos en libros ilustrados y escritura jeroglifica. Lo mismo puede afirmarse de aquellas sociedades que pudieron usar la escritura romana y escribir en lenguas aborĭgenes después de la conquista. 68

2. En general, la vida y tradición de los indios de América Latina ha sido un proceso de continuo cambio. Sus literaturas también reflejan esta constante experiencia histórica y prehistórica. De ningún modo las literaturas indígenas de América Latina deben ser reducidas a literaturas precolombinas.

3. Mientras los descendientes de los pueblos que construyeron las más grandes civilizaciones de la América antigua siguen viviendo todavía en las mismas áreas que sus antepasados, las literaturas indïgenas contemporáneas de Latinoamérica no toman sus materiales de aquellos pueblos solamente sino también de otros que no estuvieron en contacto con ellos y fueron modificados por los blancos en fechas posteriores.

4. Aunque las lenguas aborìgenes son de primera importancia para el estudio de las literaturas indígenas, el hecho es que en muchos casos tenemos más traducciones en lenguas modernas que textos originales y estamos obligados a confiar en gran medida o acaso exclusivamente en estos materiales traducidos. Si bien este enfoque no puede llevarnos muy lejos en el estudio de la poesía indígena, es ciertamente útil para el estudio de mitos y leyendas. Muchas intuiciones, imágenes y pautas mentales aborĭgenes sobreviven en las traducciones.

5. Un número creciente de indios contemporáneos han podido expresarse en su segunda lengua y de este modo ayudar a los estudiosos a comprender los antecedentes indigenas de las culturas nativas. Registros de estos textos orales españoles o portugueses pueden considerarse como una parte no despreciable de la literatura in dígena contemporánea.

6. Escritores "indigenistas" de América Latina han superado el concepto de temas indígenas como elementos exóticos en su literatura que por lo demás era formalmente europea, hispánica. Han 
transformado la literatura hispanoamericana incorporando la visión indígena a una nueva creación poética.

7. Ensayos y estudios sobre la vida y cultura indígenas han propuesto no sólo soluciones sociales, económicas y políticas a los problemas de las comunidades indígenas modernas sino también han contribuǐdo a nuestro propio conocimiento de la realidad permitiéndonos captar ideas familiares al pensamiento indígena pero no al nuestro.

8. En el estado actual de aculturación a veces es difícil trazar una clara linea de separación entre las culturas indígenas mestizas y blancas. En todo caso las literaturas indïgenas se caracterizan por el predominio de puntos de vista, estilos e imágenes que expresan modos de ver la realidad caracterǐsticos de los aborígenes americanos tradicionales.

University of Pittsburgh

JUAN ADOLFO VÁZQUEZ

\section{NOTAS}

1. Esta definición es postulada como axiomática, operacional y funcional. De otra manera podrìa argüirse, por ejemplo, que el Canadá francés es también latinoamericano, o que al sur de Estados Unidos hay paìses que no tienen origen latino, como Honduras Británica, Jamaica o Guayana. Por otra parte, como la frontera sur de Estados Unidos no ha permanecido invariable, la frontera norte de América Latina ha cambiado a través de los siglos. Hasta podria afirmarse que partes de Texas, el sud-oeste, y California siguen perteneciendo al área cultural de América Latina. Consecuentemente, tribus nativas de esos estados podrĭan ser estudiadas como indĭgenas latinoamericanos.

2. Hoy ningún antropólogo cree que los indios americanos se originaron en el Nuevo Mundo. Los "americanos nativos" son en realidad descendientes de pueblos que vinieron del Viejo mundo, muy probablemente de Asia persiguiendo la caza en la sábana de hielo que unia Siberia a Alaska hace 10,000 años. Las sucesivas oleadas de familias y grupos errantes pueden haber comenzado a internarse en América hace unos 50,000 años. Otras rutas de inmigración, menos importantes, han sido sugeridas. El problema del origen de la población nativa de América no debe confundirse con el problema de los origenes de las culturas y civilizaciones americanas nativas que alcanzaron sus niveles más altos mucho más tarde, cuando el proceso inmigratorio ya habia terminado. Los esquimales, que viven en el extremo más oriental de Siberia, Alaska, Norte de Canadá y Groenlandia, no son considerados indios americanos. Tampoco lo es la población nativa de la Isla de Pascua, dependencia de Chile en el Pacífico, cuyos aborigenes son polinesios. 
3. Como la mayor parte de las literaturas conocidas del mundo occidental han sido conservadas en escritura alfabética, existe la tendencia ampliamente difundida de pensar que la literatura es sinónimo de letras. Existen importantes partes de la literatura antigua, como las de Egipto y China, que han sido fijadas sin el uso de letras. En China, como en Japón, todavía hoy es asì. Según nuestro criterio, el punto esencial es que las literaturas no consisten en escritos sino más bien en palabras. El arte de usar palabras en las composiciones orales precede al arte de escribir y no ha sido totalmente reemplazado. Las primeras poesìas y mitologìas de Grecia e India, entre otras, fueron cantadas o recitadas antes de ser asentadas como material de lectura. Existen todavia muchos cantores y cuentistas iletrados no sólo entre las tribus de la selva y el desierto de todo el mundo sino también en sociedades civilizadas de paises islámicos e hindúes desde el Norte de Africa a Indonesia a más allá.

4. Esta clasificación sigue aproximadamente la secuencia de los periodos históricos. Serìa fácil establecer subdivisiones. Otros criterios para la clasificación podrìn ser las áreas culturales (por ejemplo: caribe, andina, amazónica, chaqueña, patagónica, etc.) o géneros literarios (ejemplo: poesĭa, mitologĭa, narrativa histórica, novelas o ensayos indigenistas modernos, etc.). Para simplificar nuestra presentación del tema no intentaremos incluir ejemplos de todos los géneros de todas las áreas culturales de cada perǐodo aun cuando fuera factible. Los trabajos citados no pretenden dar una adecuada bibliografia de la literatura indígena de Latinoamérica sino sólo ilustrar las áreas literarias que hemos establecido. Además de unos pocos clásicos, daremos preferencia a ediciones recientes en inglés y español.

5. Ver Victor Wolfgang von Hagen, The Aztec and Maya Papermakers (New York: J. J. Augustin, 1944) con muestras de papel indigena mexicano, y Hans Lenz, El papel indigena mexicano (México: Sep/Setentas, 1973, reimpreso de la edición de 1948 publicada en México por la Editorial Cultura). Ver además Fernando Martínez Cortés, Pegamentos, gomas y resinas en el México prehispánico (México: Sep/Setentas, 1974, reimpresión de la primera edición por Resistol S. A., México, 1970). Especialmente "El tzacuhtli en la fabricación del papel," pp. 65-73.

6. Ver Miguel León Portilla y Salvador Mateos Higuera, Catálogo de los códices indigenas del México antiguo. Suplemento del Boletĭn Bibliográfico de la Secretaria de Hacienda [de México] Año 3, núm. 111, junio de 1957. También: Luis Azcué y Mancera, Códices indígenas (México: Editorial Orión, 1966).

7. A algunos códices prehispánicos se les ha agregado breves notas. El contraste en las técnicas pictóricas y valores estéticos de los códices precolombinos y los del perioodo colonial temprano pueden apreciarse fácilmente en reproducciones como las incluìdas en Hans Biedermann, Mexikos heilige Bücher (Graz, Austria: Akademische Druck u. Verlagsanstalt, 1971). Se ha anunciado que están en preparación traducciones al inglés y al español de este hermoso libro.

8. Los códices mayas son designados usualmente según la ciudad donde se los conserva: Dresde, Parǐs (también Peresianus, por la palabra Peres escrita en 
el papel de la cubierta), y Madrid (o Tro-Cortesianus, por Juan Tro y Ortolano, uno de los anteriores propietarios de un fragmento, y Hernán Cortés, que se supone fue el dueño de otro fragmento). El Codex Dresde es el más importante de ellos, y de incomparable valor para el estudio de los jeroglíficos y la astronomía mayas. Ha sido publicado varias veces. Ver A Commentary on the Dresden Codex, A Maya Hieroglyphic Book, por J. Eric S. Thompson (Philadelphia: American Philosophical Society, 1972), que incluye el facsimil de sus páginas pero es particularmente notable por la interpretación de los contenidos. La mejor reproducción en colores en el formato original es el Codex Dresdensis, Sächsische Landesbibliothek Dresden (Mscr. Dresd. R. 310), una edición fascimilar con comentario de la historia del manuscrito por Helmut Deckert, y descripción por Ferdinand Anders (Graz, Austria: Akademische Druck-u. Verlagsanstalt, 1975). Los tres códices may as han sido reproducidos en blanco y negro, con descripción de sus contenidos, en Antonio Villacorta C. y Carlos A. Villacorta, Códices mayas. Dresdensis, Peresianus, Tro-Cortesianus (Guatemala: no se indica editor, 1933). Un pequeño libro reciente para el gran público incluye muestras en blanco y negro de los códices: Guillermo Garcés Contreras, Los códices mayas (México: Sep/Setentas, 1975).

9. En su lista de rasgos caracteristicos de Mesoamérica Paul Kirchhoff incluye "escritura jeroglifica, signos de números y de sus valores relativos de acuerdo a la posición; libros doblados como un biombo, anales históricos y mapas." Ver su artículo "Mesoamérica: Its Geographic Limits, Ethnic Composition and Cultural Characteristics" traducido por Norman McQuown de Acta Americana, vol. 1, No. 1, 1943), reimpreso de Heritage of Conquest, editado por Sol Tax (New York: The Macmillan Company, 1952), y también en Ancient Mesoamerica, Selected Readings, editado por John A. Graham (Palo Alto, California: Peek Publications, 1966), p. 9.

10. Por ejemplo, el Códice Mendoza, un documento del colonial temprano, ha sido descripto por Miguel León Portilla y Salvador Mateos Higuera como de contenido histórico tributario y etnógrafico (op. cit. p. 18). Su primera página, a menudo reproducida, ha sido explicada como "la fundación de la ciudad de México-Tenochtitlán dividida en cuatro partes limitada por canales." (Ver la interpretación de José Corona Núñez del códice en Antigüedades de México basadas en la recopilación de Lord Kingsborough [México; Secretarìa de Hacienda y Crédito Público, 1964, p. 6]). Pero la pintura también podria ser interpretada como una representación de México-Tenochtitlán como el centro del universo, con las cuatro direcciones cósmicas indicadas por los "canales." Esta mezcla de saber geográfico y simbolismo mittico-religioso es común también en mapas medievales, donde a Roma y/o a Jerusalén se les da posiciones centrales. Ver también Codex Mendoza, manuscrito mexicano conocido como Colección de Mendoza y conservado en la Biblioteca Bodleian, Oxford, editado y traducido por James Cooper Clark (London: Waterlow and Sons Ltd. 1938, 3 tomos). Las reproducciones están en blanco y negro.

11. El progreso en el desciframiento e interpretación de los códices mayas no puede separarse de la publicación de algunos estudios del maya clásico y del 
desciframiento de inscripciones. Entre los primeros, el más importante jalón fue la primera edición de Diego de Landa, Relación de las cosas de Yucatán, en una traducción francesa por C. E. Brasseur de Bourbourg (Relation des choses de Yucatan, Paris: 1864). Acerca de las inscripciones, más detalles en seguida. Ver la sección de J. Eric S. Thompson "Search and Research" en su Maya Hieroglyphic Writing (Norman: University of Oklahoma Press, 3era. edición, 1971, pp. 28-34). Este libro es un granero colmado de detalles acerca de muchos aspectos de la civilización maya, en realidad uno de los mejores que pueden recomendarse como introducción a los estudios mayas.

12. Las cualidades estéticas de los códices precolombinos han sido justamente subrayadas por un gran número de autores. Ver por ejemplo, Luis Cardoza y Aragón, "Aproximaciones al Códice Borgia," en Cuadernos Americanos, vol, XXIII, no. 2, Marzo-Abril 1964, pp. 167-175, y Raúl Flores Guerrero, Historia general del arte mexicano, Epoca prehispánica (México: Editorial Hermes, 1962), capítulo 7: "Los libros mágicos del México antiguo," pp. 117-124.

13. Un gran progreso en la historia de nuestro conocimiento de los códices mexicanos fue la edición a cargo de E. K. Kingsborough, con dibujos por A. Aglio, bajo el tìtulo de Antiquities of Mexico (London: Robert Havell, 1831-1848). (Esta rara edición en folio mayor puede ser consultada en el Darlington Room de la Cathedral of Learning, Universidad de Pittsburgh.) La edición mexicana, en parte adaptada de Kingsborough, con comentarios en español por José Corona Núñez, fue citada más arriba (ver nota 10). Eduard Seler contribuyó en gran medida al aumento de nuestra comprensión de los códices mediante sus ediciones y comentarios del Fejérvary-Meyer, Vaticanus y Borgia. Ver Eduard Seler (1) An Old Mexican Picture Manuscript in the Liverpool Free Public Museum, 12014/M, traducido por A. H. Keane (Berlin and London: publicado a costas de su Excelencia el Duque de Loubat, 1901-1902). (2) Codex Vaticanus No. 3773 (Vaticanus B), An Old Mexican Pictorial Manuscript in the Vatican Library, traducido por A. H. Keane (Berlin and London: publicado a costas de su Excelencia el Duque de Loubat, 1902-1903). (3) Codex Borgia: An altmexikanische Bilderschrift der Bibliothek der Congregatio de Propaganda Fide (Berlin: herausgegeben auf Kosten Seiner Excellenz der Herzog von Loubat, 1904-1909, 3 tomos). De la última edición mencionada hay una traducción española por Mariana Frenk: Códice Borgia (México: Fondo de Cultura Económica, 1963, 3 tomos). Ediciones modernas, con comentarios, de los códices Mendoza y Dresden, han sido mencionadas más arriba. Ver también el interesante libro por Karl Anton Nowotny, Tlacuilolli: Die mexikanischen Bilderschriften. Stil und Inhalt, mit einem Katalog der Codex-Borgia Gruppe (Berlin: Verlag Gebr. Mann, 1961). El título se refiere, en náhuatl, a los artistas del México antiguo que pintaron los códices. Este libro es una interesante introducción al estudio de los códices relacionados con el Borgia. Alfonso Caso subrayó el contenido histórico y genealógico de algunos códices mixtecas. Ver Interpretación del Códice Bodley, 2858 (México: Sociedad Mexicana de Estudios Antropológicos, 1960), e Interpretación del Códice Selden 3135 (A2) 
(México: Sociedad Mexicana de Estudios Antropológicos, 1964). Mediante el estudio de las caracterìsticas estilisticas, Donald Robertson ha sugerido otro modo de enfoque. Ver su artículo "The Mixtec Religious Manuscripts," Ancient Oaxaca, Discoveries in Ancient Archeology and History, editado por John Paddock (Stanford, California: Stanford University Press, 1966), pp. 298-312.

14. Ver John B. Glass, Catálogo de la colección de códices [del Museo Nacional de Antropologia] (México: Museo Nacional de Antropología, Instituto Nacional de Antropologia e Historia, 1964). Caso también discute problemas calendáricos de los códices. Ver su importante libro Los calendarios prehispánicos (México: UNAM: Instituto de Investigaciones Históricas, 1967), particularmente el capitulo 3, "Comentarios al Códice Borbónico," pp. 101-140. Este libro es una edición revisada y aumentada de muchos trabajos antes publicados separadamente.

El estudio de los códices mesoamericanos ha sido afectado por la falta de ediciones adecuadas que deberian incluir fieles reproducciones de los libros pintados, en sus verdaderos colores y el mismo formato que el original, y un ensayo descriptivo e interpretativo de su contenido. La primera desventaja se está superando gracias a los excelentes facsimiles publicados por la Akademische Druck und Verlagsanstalt de Graz, Austria. Hasta ahora los siguientes han llegado a nuestro conocimiento: Becker I/II (1961), Vindobonensis Mexicanus 1 (1963), Egerton 2895 (1965), Laud (1966), Tro-Cortesianus (1967), Perésianus (1968), Cospi (1968), Magliabechiano (1968), Fejérváry-Mayer (1971), Vaticanus 3773 (1972), y Dresdensis (1975). En cuanto al segundo punto, no hay todavia una solución a la vista. Los eruditos y a menudo reveladores comentarios de Eduard Seler citados en la nota anterior, no han sido continuados por exégesis similares de investigadores recientes; sin embargo, para algunos otros códices tenemos adecuadas ediciones de uso práctico (ver notas 10 y 13). Por otro lado, una creciente toma de conciencia de la importancia de los códices precolombinos como obras de arte y literatura se refleja en cierto número de pequeños libros populares como C. A. Burland, Magic Books from Mexico (Harmondsworth: Penguin Books, 1953, reimpreso en México: Ediciones Lara, 1966) y también Maria Stern, Las extraordinarias historias de los códices mexicanos (México: Joaquin Mortiz, 1972). Ambos tienen dibujos en colores, y el segundo ofrece además muchas ilustraciones en blanco y negro. El breve volumen publicado en México en 1973 bajo el título de La maldición de los códices mexicanos procura demostrar que cuarenta estudiosos dedicados al estudio de los códices terminaron sus vidas trágicamente. El libro tiene poco valor científico, pero atestigua el hecho de que los códices mexicanos, primeramente objeto de especialistas, ahora están al alcance del hombre de la calle. No obstante, hay pruebas de que pueden hacerse aceptables reproducciones en colores en ediciones económicas. Ver The Codex Nuttall, un manuscrito ilustrado del antiguo México editado por Zelia Nuttall con un nuevo tex to introductorio por Arthur G. Miller (New York: Dover Publications, 1975). Aunque no puede compararse con los costosos facsǐmiles de Graz, la reimpresión neoyorquina de la edición de 1902 de códice Nuttall es una valiosa adición al reducido número de códices actualmente 
disponibles en librerias. Desgraciadamente, la introducción deja mucho que desear. Es de esperar que pronto haya más reproducciones económicas de este tipo, con mejores introducciones.

15. Ver J. Eric S. Thompson, Maya Hieroglyphic Writing, citado en la nota 11. El clásico libro de Silvanus Griswold Morley, An Introduction to the Study of the Maya Hieroglyphs (Washington, D.C., Bulletin 57 of the Bureau of American Ethnology, Smithsonian Institution, 1915) ha sido reimpreso con una introducción biográfica y una bibliografia puesta al día por Eric S. Thompson (New York: Dover Publications, 1975). Este útil manual solamente trata de glifos relacionados al calendario maya.

16. Ver Tatiana Proskouriakoff, "Historical Implications of a Pattern of Dates at Piedras Negras, Guatemala," en American Antiquity, vol. 25, pág. 454-475, 1960; "Portraits of Women in Maya Art," en Essays in Pre-Columbian Art and Archeology, Cambridge, Mass.: Harvard University Press, 1961, pág. 81-89; e "Historical Dates in the Inscriptions of Yaxchilan," in Estudios de Cultura Maya, vol. 3, pág. 149-167, México, 1963-1964.

17. La escritura del alfabeto cretense que ha llegado hasta nosotros muestra que los antiguos griegos usaron un sistema gráfico para contabilizar las mercancías en los cuartos de almacenaje y similares prácticas inventariales más bien que para registrar poeš̀as $\mathrm{u}$ otras formas de literatura. Platón decía que ningún hombre serio jamás pensarìa escribir sobre cosas serias (Séptima carta $344 c$ ), y que nada que haya sido escrito en prosa o en verso merece seria atención (Fedro 277e).

18. Algunos códices generalmente considerados precolombinos llevan notas en español, hecho que ha llevado a confusión respecto al origen de los documentos. Para los presentes propósitos es más apropiado subrayar la supervivencia de las antiguas tradiciones que cavilar sobre la destrucción de innumerables códices $\mathrm{y}$ otras obras de arte irreparablemente perdidas debido al fanatismo de los conquistadores. Para los códices del temprano colonial ver fuentes citadas en las notas 6 y 14. Además de las reproducciones facsimilares de los códices prehispánicos, Akademische Druck und Verlagsanstalt ha anunciado otra serie, Fontes Rerum Mexicanorum, editada por Ferdinand Anders, que incluirá obras del colonial temprano tales como pequeños códices, anales, listas de tributos y "lienzos." Las siguientes han sido anunciadas: Anales de Tula (del estado de Hidalgo, siglo XVI), Códice Azoyú (del estado de Guerrero, siglo XVI), Lienzo de Zacatepec (del este de Oaxaca, Siglo XVI) y el Códice Porfirio Díaz (del norte de Oaxaca, Siglos XVI y XVII, con algunas páginas de escenas calendárico-rituales de los códices pre-colombinos similares a los del grupo Borgia.

19. Ver nota 7.

20. El anónimo Anales históricos de la Nación Mexicana o Anales de Tlatelolco fue escrito en náhuatl entre tres o cuatro años después de la caĭda de Tenochtitlán. Ver Willard P. Gingerich, "A Bibliographical Introduction to Twenty Manuscripts of Classic Nahuatl Literature," en Latin American Research Review, vol. 10, no. 1 (Spring 1975), p. 119.

21. Fernando Alvarado Tezozomoc era un indio, nieto de Moctezuma y 
biznieto de Axayael, sexto monarca de Tenochtitlán. Escribió en náhuatl crónicas mexicanas alrededor de 1609 , relatando la historia de los mexicanos desde la época en que abandonaron la tierra mítica de Atzlán hasta el año 1519 cuando los españoles entraron en Tenochtitlán. Tezozómoc continúa su crónica en forma de anales hasta que alcanza el año del nueve colorado o 1578, su última entrada. Ver Crónica Mexicáyotl, tex to y dos traducciones paralelas por Adrián León (México: UNAM, 1949: reimpreso en 1975).

Juan Bautista Pomar fue un mestizo, hijo de un español y una mujer india cuyo padre fue el rey Nezuhualpitzinli. También describió pinturas, a las que remite al lector, pero que no han llegado hasta nosotros. Su Relación de Texcoco ha sido elogiada como una monografía histórica veraz. Joaquîn Garcỉa Icazbalceta la incluyó en su Nueva Colección de Documentos para la Historia de México (México: Díaz de León, 1891), vol. VII, p. vii-xi y 1-69.

Fernando de Alva Ixtlilxochitl (1568? -1648?) fue también descendiente de un ilustre noble de Tezcoco y Tenochtitlán. Escribió en náhuatl varias narraciones históricas breves tomadas de las doctrinas incluidas en antiguos cantos y libros pintados. Ellas tratan de los toltecas, chichimecas, las estatuas del poetarey Nezahualcoyotl, la llegada de los españoles, su entrada en Texcoco y otros. Algunas de estas piezas fueron traducidas al español por el alguacil Francisco Rodrĭguez. Como Ixtlilxochitl tenía esperanzas de recobrar su pequeño reino refundió sus opúsculos náhuatles en español y produjo un breve informe para los virreyes mexicanos. Su Historia chichimeca, en español, ha sido elogiada como una obra bien escrita. Fue incluida por Kingsborough en su Antiquities of Mexico (London, 1831-1848, vol. 9, p. 147-316). Los trabajos históricos de Ixtlilxochitl fueron publicados por Alfredo Chavero, vol. 1, Relaciones, vol 2, Historia chichimeca (México: Secretarĭa de Fomento, 1891-1892).

Domingo de San Antón Munón Chimalpáin (nacido en 1579, fue en 1620 administrador de una institución religiosa, escribió en náhuatl ocho "relaciones" o relatos los cuales han sido parcialmente traducidos al español, francés o alemán. Como muchos otros escritores coloniales, trata de coordinar tradiciones indígenas americanas con los relatos biblicos de la creación e historia cristiana. Sus textos, Diferentes historias originales de los reynos de Culhuacán y México, y de otras provincias, fueron editados por Ernst Mengin en el Corpus Codicum Americanorum Medii Aevi, vol. 3, parte 1 y 2 (Hauniae [Copenhagen], Munksgaard, 1949).

Diego Muñoz Camargo fue un mestizo, hijo de un español y una mujer india de noble linaje tlaxcalteca. Su famosa Historia de Tlaxcala, escrita en español, utiliza viejas tradiciones nativas y fue aprovechada por posteriores historiadores españoles antes de ser publicada como Historia de la ciudad y República de Tlaxcala, con notas de Alfredo Chavero (México: Secretaría de Fomento, 1892).

Los ejemplos anteriores demuestran que una división rigurosa entre literatura indigena e hispanoamericana basada en la lengua es difïcil de sostener.

22. El texto español original de la monografía por Juan Ramón Pané, sacerdote que vino al Nuevo Mundo en el segundo viaje de Colón, se ha perdido, 
pero fue incorporado por Fernando, el hijo de Colón, como un capítulo de su biografìa del Almirante. Este libro ha llegado a nosotros en una versión italiana, de la cual hay una traducción al inglés por Benjamin Rand: The Life of the Admiral Christopher Columbus by His Son Ferdinand (New Brunswick, N. J.: Rutgers University Press, 1959). El breve tratado de Pané ocupa las págs. 153-165. Existe una antigua traducción de Pané por Edgar Gaylor Bourne: Columbus, Ramón Pané and the Beginnings of American Anthropology (Worcester, Mass.: Proceedings of the American Antiquarian Society, n.s., XII, 1906, p. 310-384). La mejor edición ha sido preparada por José Juan Arrom; Fray Ramón Pané, "Relación acerca de las antigüedades de los indios," el primer tratado escrito en América. Nueva versión con notas, mapa y apéndices (México: Siglo XXI editores, 1974). Ver también Juan José Arrom, Mitología y artes prehispánicas de las Antillas (México: Siglo XXI editores, 1975).

23. Entre los poetas aztecas, muchos de ellos anónimos, la obra de Nezahualcoyotl ha sido justamente alabada. Ver Miguel León Portilla, Nezahualcoyotl (Texcoco: Gobierno del Estado de México, 1972). Ahora es posible vincular en creciente número de poetas a los poemas en náhuatl. Ver León Miguel Portilla, Trece poetas del mundo azteca (México: UNAM, 1967). Hay colecciones anónimas de literatura náhuatl que contienen piezas cuyos autores pueden ser identificados. Pueden también incluir textos en español, como el Códice Chimalpopoca, la segunda parte del cual fue escrita en español por el padre Pedro Ponce, de Tzumpahuacan (1569) bajo el título de "Tratado de los dioses y ritos de la gentilidad," publicados por Angel Marìa Garibay en Teogonía $e$ historia de los mexicanos, Tres opúsculos del siglo XVI (México: Editorial Porrúa, 1965). La primera parte del códice, Anales de Cuauhtitlán, fue anónimamente escrita en náhuatl en 1570; la tercera parte, La leyenda de los soles, también anónima, fue escrita en náhuatl en 1558. Las partes náhuatles han sido publicadas por Walter Lehmann con una traducción al latìn: Die Geschichte der Königreiche von Colhuacan und Mexico, Quellenwerke zur alten Geschichte Amerikas, vol. 1, Stuttgart: Kohlhammer, 1938. Hay una traducción en español del náhuatl por Primo Velázquez, Códice Chimalpopoca: Anales de Cuauhtitlán $y$ Leyenda de los Soles (México: UNAM, 1945); reimpreso en 1975). Esta edición incluye una ilegible reproducción fotográfica del texto.

24. La obra compilada por Sahagún comprende tres extensos códices: el Códice matritense del Real Palacio, compuesto en Tepepulco, Tlatelolco y Mexico-Tenochtitlán entre 1547 y 1565; el Códice matritense de la Real Academia de la Historia, redactado en el Colegio de Santa Cruz de Tlatelolco entre 1560 y 1565; y el Códice florentino, escrito en Tepepulco, Tlatelolco and México-Tenochtitlán entre 1547-1580. Los Códices matritenses han sido publicados sólo parcialmente; muchos extractos han sido traducidos y publicados en diversas lenguas. El Códice florentino, que repite el contenido de los otros dos y agrega otros materiales, ha sido editado y traducido al inglés por Arthur A. O. Anderson y Charles Dibble, Florentine Codex (Salt Lake City: The School of American Research and the University of Utah, 12 vols., 1950-1969). E1 volumen introductorio y el ìndice no han sido publicados aún. Existen varias 
ediciones del texto español del Códice florentino, la última por Angel Marĭa Garibay: Fr. Bernardino de Sahagún, Historia general de las cosas de Nueva España (México: Editorial Porrúa, 2da edición, 1961, 4 tomos).

25. La primera edición del trabajo de Landa fue mencionada en la nota 11. Se basaba en una antigua copia abreviada de por otro autor, pues el manuscrito de Landa se ha perdido. Han habido otras ediciones y traducciones del mismo texto. Una versión inglesa por varios traductores ha sido dotada de extensos comentarios e indices por Alfred M. Tozzer: Landa's Relación de las cosas de Yucatán (Cambridge, Mass.: Papers of the Peabody Museum of American Archeology and Ethnology, Harvard University, 1941; reeditada en Nueva York por Kraus Reprint Corp. en 1966). La edición de Tozzer es una obra maestra de los estudios maya. La última edición española, por Angel Maràa Garibay, fue publicada en México por la Editorial Purrúa en 1966.

26. Entre los mestizos que escribieron en español incorporando antiguas tradiciones estuvo Cristóbal de Molina, de Cuzco. Sus Relación de fábulas y ritos de los Incas fue traducida por Clemens Robert Markham: Fables and Rites of the Incas 1570-1584 (London: The Haykluyt Society, 1873), publicada en español por Thomas Thayer Ojeda en Revista de Historia y Geografía, vol. 5, Santiago, Chile, 1913, y por Carlos A. Romero en "Colección de libros y documentos referentes a la historia del perú (Lima: Sanmartí, 1916, vol. 1, p. 1-103). Ver también Theodoro L. Meneses, Nueva traducción de preces o himnos quechuas del cronista Cristóbal de Molina, el cuzqueño (de Relación de fábulas y ritos de los Incas) (Lima: Universidad Nacional Mayor de San Marcos, 1964).

27. Garcilaso de la Vega, hijo ilegítimo de un distinguido capitán español y una mujer relacionada con los reyes incas, puede ser igualmente considerado como un representante de la literatura española del siglo de oro y como un mestizo orgulloso de su conocimiento directo de tradiciones que escuchó en quechua cuando era niño. Existen varias ediciones y traducciones de sus trabajos sobre cultura e historia del Perú, por ejemplo: Comentarios reales de los Incas, editado por Angel Rosenblat (Buenos Aires, Emecé, 1943, 2 t.), Historia general del Perú, editada por José Durand (Lima: Universidad Nacional Mayor de San Marcos, 1962-1963, 4 t.) y Royal Commentaries of the Incas and General History of Peru, traducidos por Harold V. Livermore (Austin: University of Texas Press, 1966, 2 tomos). Entre las fuentes escritas, Garcilaso pudo usar fragmentos de la obra inédita de Blas de Valera, Historia Occidentalis, rescatados del ataque inglés a Cádiz (1596) donde se perdió el resto del manuscrito. Blas de Valera (1543? -1597), hijo de uno de los capitanes de Pizarro y una noble dama india, se hizo sacerdote jesuita, hablaba con los indios quechua y aymara, y escribió sus tradiciones, incluyendo ejemplos de poesĩa quechua.

28. La extraordinariamente larga carta de Guamán Poma de Ayala al rey español fue descubierta en la colección real de Copenhague en 1908 y publicada en facsímil como Nueva Corónica y Buen Gobierno (Codex Peruvien illustré), (Université de Paris, Institut d'Ethnologie, Paris, 1936). Una edición más legible fue editada por Arthur Posnansky: La obra de Phelippe Guamán Poma de Ayala: "Primer Nueva Corónica y Buen Gobierno" (La Paz, Bolivia: Instituto "Tia- 
huanacu," 1944). Luis Bustios Gálvez refundió los tex tos quechua y español de Guamán Poma en una moderna versión española: La "Nueva Crónica y Buen Gobierno" escrita por Don Felipe Guamán Poma de Ayala (Lima: Editorial Cultura, 1956-1966, 3 tomos). Otro autor indio que escribió en un español incorrecto e insertó largas frases en quechua fue Juan de Santa Cruz Pachacuti Yamqui Salcamaygua, que se declaraba cristiano aunque su obra muestra que seguia conservando antiguas creencias aborigenes. Su Relación de antigüedades deste Reyno del Perú (alrededor de 1613) fue incluìdo por Marcos Jiménez de la Espada en Tres relaciones de antigüedades peruanas (Madrid: M. Tello, 1879), también por Horacio H. Urteaga en su "Colección de libros y documentos referentes a la historia del Perú," tomo 9 (Lima: Sanmartǐ, 1927), y por Francisco Esteve Barba en Crónicas de interés indígena (Madrid: Atlas, 1968). Hay una traducción inglesa por Clemens Robert Markham en Fables and Rites of the Yncas (ver nota 27).

29. Existen varias ediciones y traducciones de los textos españoles y quechuas de Avila. Una traducción inglesa ("A Narrative of Errors, False gods, and Other Superstitions and Diabolical Rites. ..") del texto español de Avila de 1608 fue incluída por Markham en su Narratives of the Rites and Laws of the Indians (ver nota 27). La edición por Hermann Trinborn: Dämonen und Zauber in Inkareich (Leipzig: Koehler, 1939) tiene una traducción alemana, e imprime el texto quechua de 1598 por primera vez. La edición preparada por Hipólito Galante ofrece el facsïmil del manuscrito quechua de 1598, su traducción latina, y una traducción española de la versión latina: Francisci de Avila de priscorum huaruchiriensium origine et institutis. . . (Madrid: C.S.I.V., 1942). La traducción española por José Marìa Arguedas, con la transcripción del texto quechua: Dioses y hombres de Huarochirí (Lima: Museo Nacional de Historia e Instituto de Estudios Peruanos, 1966), ha sido reimpresa omitiendo el texto quechua y otros materiales (México: Siglo XXI, 1975). Menos importante para nuestro conocimiento de las tradiciones orales quechuas pero interesante por sus antecedentes religiosos es el trabajo del jesuita español Pablo José de Arriaga: Extirpación de la idolatría del Perú, impreso en Lima con algunas omisiones introducidas por editores temerosos en 1621. Fué incluìdo por Jiménez de la Espada en Tres relaciones de antigüedades peruanas (ver nota 29), traducción inglesa por Clark Keating: The Extirpation of Idolatry in Peru (Lexington: The University Press of Kentucky, 1968).

30. Los escritos de los principales navegantes, exploradores y conquistadores han sido publicados separadamente y en colecciones. Uno de ellos es Martìn Fernández de Navarrete en Colección de viajes y descubrimientos que hicieron por mar los españoles (Madrid, 5 v., 1825-1837; reimpreso en Buenos Aires: Editorial Guarania, 1945).

31. De regreso de su primer viaje de América, Colón escribió dos cartas, prácticamente con el mismo contenido, a dos oficiales de la corona. Una de ellas fue publicada en Barcelona, en abril de 1493. Fue prontamente trasladada al latín y publicada en nueve ediciones separadas en diferentes paîses europeos. La siguió una versión italiana en verso, y muchas otras. Ver Christopher Columbus, 
Four Voyages to the New World: Letters and Selected Documents Translated and Edited by R. H. Major. Introduction by John E. Fagg. Bilingual Edition (New York: Corinth Books, 1961). En esta edición la introducción de Fagg reemplaza la de Major la cual fue publicada en la primera edición (London: The Hakluyt Society, 1847).

El diario de navegación del primer viaje de Colón ha sido conservado en un largo resumen que incluye muchos pasajes del original, hecho por Bartolomé de Las Casas. Fué publicado por primera vez en la colección Navarrete (ver nota 31) y nuevamente editado por otros especialistas, así como traducido a varias lenguas. La mejor edición inglesa es Columbus' Journal traducido por Cecil Jane, revisado y anotado por L. A. Viqueras, con un apéndice por R. A. Skelton (New York: Clarkson N. Potter, 1960) y Samuel Eliot Morison (editor), Journals and Other Documents on the Life and Voyages of Christopher Columbus (New York: The Heritage Press, 1964). El breve tratado de Pané sobre las primitivas tradiciones de la Española (ver nota 23) se relaciona con el segundo viaje de Colón.

32. El ensayo de Montaigne sobre los canibales (1580) fue la primera discusión erudita acerca del carácter de los nativos americanos. Montaigne considera que la supuesta antropofagia que se les atribuia no era peor que las prácticas europeas de esa época. La traducción inglesa de los Essais de Montaigne (1603) de Giovanni Florio es probablemente la fuente de Caliban en La tempestad de Shakespeare. El tema del bon sauvage usado contra la creencia en la intrinsica maldad del hombre favoreció la doctrina política de los derechos humanos y el desarrollo de las instituciones democráticas. Para el tema del bon sauvage en literatura ver la bibliografía al final del artículo sobre "Primitivism" en Philip P. Wiener, editor, Dictionary of the History of Ideas (New York: Scribner, 1973), vol. 2, p. 582-583. El mismo motivo se encuentra en el fondo de las polémicas modernas acerca del indigenismo. El tema del buen salvaje y el canibal asumió nuevas dimensiones en las discusiones europeas sobre las cualidades físicas y morales de los indios americanos. Ver Antonello Gerbi, La disputa del Nuovo Mondo; storia di una polemica, 1750-1900 (Milano: Ricciardi, 1955), traducción inglesa revisada y aumentada por Jeremy Moyle: The Dispute of the New World; the history of a Polemic, 1750-1900 (Pittsburgh: University of Pittsburgh Press, 1973).

33. Las cinco Cartas de relación de Hernán Cortés al Emperador Carlos V fueron escritas entre 1519 y 1526 . Como la primera carta se ha perdido, es comúnmente reemplazada por un documento similar de los regidores de Veracruz. Algunas de las cartas de Cortés fueron publicadas en España en el siglo XVI y las cuatro que quedan en Paris (Chaix, 1866) por Pascual Gayangos, cuyo texto ha sido seguido en recientes reimpresiones económicas. La mejor edición es el facsímil del Codex Vindobonensis, S. N. 1600, con texto en español: Cartas de relación de la conquista de Nueva España escritas por Hernán Cortés al Emperador Carlos V, y otros documentos relativos a la conquista, años de 1519-1527, introducción por J. Stummvoll, comentarios por Charles Gibson, y descripción del códice por F. Unterkircher (Graz: Akademische Druck- und Verlagsanstalt, 
1960). La mejor edición inglesa es Letters from Mexico, traducida y editada por A. R. Pagden, con introducción por J. H. Elliot (New York: Grossman, 1971). La segunda carta de Cortés contiene un pasaje en el cual intenta reproducir literalmente el discurso de Moctezuma de bienvenida, donde tiene lugar la primera mención del mito de Quetzalcoatl en español.

34. El tex to de Bernal Díaz del Castillo Historia verdadera de la conquista de la Nueva España fue conocido en España a través de copias que fueron usadas por historiadores del siglo XVII. Fue publicado muy imperfectamente en 1632. En 1840 el manuscrito original fue encontrado en Guatemala y publicado por Genaro García en 1906 de una fotocopia. Existen muchas reimpresiones populares asï como varias traducciones. La mejor traducción inglesa es la de A. P. Maudsley: The True History of the Conquest of New Spain (London: The Hakluyt Society, 1908-1916). La traducción de J. M. Cohen, The Conquest of New Spain (Harmondsworth: Penguin Books, 1963) está muy abreviada. Aunque sería difícil poder sostener que Bernal Díaz estaba interesado en las antiguas literaturas y culturas mexicanas, su descripción de primera mano de importantes personalidades indias, incluso Doña Marina (mejor conocida como La Malinche, intérprete y amante de Cortés) se han convertido en fuentes imprescindibles para nuestro conocimiento de la civilización azteca.

35. Cuando Alfonso Reyes escribió su breve libro Visión de Anáhuac (San José, Costa Rica: Alsina, 1917) fue inspirado por la descripción que los primeros conquistadores hicieron de Tenochtitlán. El título de la novela de Carlos Fuentes, La región más transparente recuerda la misma visión, ahora perdida en el humo industrial de la moderna ciudad de México.

36. En el periodo colonial temprano algunas descripciones de las sociedades de indios sudamericanos fueron redactadas por escritores no hispánicos como los alemanes Ulrich Schmidel y Hans Staden, el fraile francés André Thevet y el noble isabelino Sir Walter Raleigh. Existen muchas antiguas ediciones y traducciones del libro de Schmidel Wahrhafftige und liebliche beschreibung etlicher füernemen indianischen landtschafften und insulen die vormals in keiner chronicken gedacht und erstlich in der schriffart Vlrici von Straubingen mit grosser gefahr erkündigt und von ihm selber auffs fleissigst beschrieben und dargethan (primera edición alemana: Frankfurt, 1567). El manuscrito de 1554 fue usado por Edmundo Wernicke en la traducción española, Derrotero y viaje a España y las Indias, por Ulrico (Utz) Schmidl (Santa Fe, Argentina: Universidad Nacional del Litoral, 1928; reimpreso con prólogo por Enrique Gandia en "Colección Austral" No. 424, Buenos Aires: Espasa-Calpe, 1944). El libro de Hans Staden Wahrhaftige historia und beschreibung eyner landschaft der wilden nacketen grimmigen menschfresser leuthen in der newenwelt Amerika (Margurg, 1557) fue trasladado al inglés como The captivity of Hans Staden of Hesse, in A.D. 1547-1555 among the wild tribes of eastern Brazil por Albert Tootal, $y$ anotado por Richard F. Burton (London: The Hakluyt Society, 1893), y como Hans Staden, The true history of his captivity, 1557, traducido y editado por Malcolm Letts (London: Routledge, 1928; New York: McBride, 1929). La traducción portuguesa por Alberto Löfgren, con notas por Teodoro Sanpairo, Hans 
Staden, Suas viagens e captiverio entre os selvagems do Brazil (Sao Paulo: Instituto Historico, 1900) fue retraducido al español por Marǐa E. Fernández como Viajes y cautiverios entre los canibales (Buenos Aires: Nova, 1945). Existe también una traducción española del alemán por Edmundo Wernicke: Vera historia y descripción de un país de las salvajes desnudas feroces gentes devoradoras de hombres situado en el nuevo mundo América (Buenos Aires: Coni, 1944). El libro de André Thevet sobre América es importante: Les singularités de la France Antartique, autrement nomée Amérique, et de plusieurs terres et isles decouverts de notre temps (Paris, 1557), y La cosmographie universelle (2 vols., Paris, 1575) contiene descripciones de la mitología tupinambá. El libro de Sir Walter Raleigh The Discovery of Guiana (London: Robert Robertson, 1596) ha sido reimpreso en facsímil por The World Publishing Company (Cleveland, Ohio, 1966).

37. La primera descripción de una batalla con mujeres guerreras en América fue hecha por Gaspar de Carvajal, fraile dominicano que acompañó a Francisco de Orellana en su expedición al Amazonas. El relato de Carvajal fue impreso con algunos cambios por Gonzalo Fernández de Oviedo en su Historia general y natural de las Indias (ver nota 40). Otro manuscrito fue editado por José Toribio Medina: Descubrimiento del rio de las Amazonas según la relación. . de fray Gaspar de Carvajal (Sevilla: Rasco, 1894); reimpreso en Bogotá: Biblioteca Nacional, 1942, etc.). Traducción inglesa por B. T. Lee, The Discovery of the Amazon according to the account of Friar Gaspar de Carvajal (New York: American Geographical Society, 1934). La leyenda de las amazonas americanas ha sido estudiada por varios investigadores, por ejemplo, Hartley Burr Alexander, "The Amazons," en The Mythology of All Races, v. XI: Latin America (Boston: Marshall Jones Co., 1920; reimpreso: New York: Cooper Square Publishers, 1964), p. 281-287. Ver también Carlos Alonso del Real, Realidad y leyenda de las Amazonas (Madrid: Colección Austral No. 1398, Espasa-Calpe, 1967) que proporciona documentos para la leyenda en el Viejo y Nuevo Mundo.

38. Se considera que Pedro Cieza de León (1520? -1544) es el más grande cronista español de la antigua historia y conquista del Perú. Además de escribir sobre la Conquista y las guerras civiles de los españoles en el Perú, trató de reconstruir el pasado prehispánico andino. Para este propósito hizo investigaciones entre las más antiguas personalidades incas. También informó acerca de la existencia de grandes monumentos antiguos y describió el impacto corruptor de los brutales conquistadores en las civilizadas sociedades incaicas. Su obra ha sido publicada en fragmentos a lo largo de los siglos. La primera parte apareció un año antes de la muerte del autor: La primera parte de la Crónica del Perú (Sevilla, 1553). Su largo título explićitamente dice que trata, entre otras cosas, de los "ritos y costumbres de los indios." fue reimpreso con éxito varias veces, traducido al italiano (Roma, 1555), al inglés por John Stevens (London, 1709) y por Clements R. Markham: The Travels of Pedro Cieza de León, A.D. 1532-50, contained in the first part of his Chronicle of Peru (London: The Hakluyt Society, 1864). La segunda parte, de considerable interés para la historia incaica, permaneció sin publicar por largo tiempo, pero una copia del manuscrito fue 
usada más tarde por historiadores españoles. Fue publicado por Marcos Jiménez de la Espada in Biblioteca Hispana Ultramarina, t. 5 (Madrid, 1880). La traducción inglesa por Clements R. Markham: The Second Part of the Chronicle of Peru (London: The Hakluyt Society, 1883) ha sido severamente censurada como una falsificación deliberada del original. Ver también Pedro Cieza de León, The Incas, traducida por Harriet de Onís, editada con una introducción por Victor Wolfgang von Hagen (Norman: The University of Oklahoma Press, 1959). La tercera parte trata de la conquista, y la cuarta está dedicada a la guerra civil. Hay una moderna edición económica de la primera parte en la Colección Austral, no. 597, La crónica del Perú (Madrid: Espasa-Calpe, 1945, y reimpresiones posteriores).

Juan de Betanzos, que murió muy viejo en 1576, fue uno de los primeros españoles que aprendió la lengua quechua. Fue intérprete de Pizarro. En Cuzco se casó con la princesa Añas Kollka, la hija del Inca Huaina Capac y hermana de Atahualpa. En su casa hablaba quechua con los nobles incas. El manuscrito de su Suma y narración de los Incas que los indios llaman Capaccuna etc., escrita alrededor de 1551, fué usada por Prescott. El manuscrito existente es incompleto. Fue publicado por Marcos Jiménez de la Espada en Biblioteca Hispana Ultramarina, t. 5 (Madrid, Hernández, 1880). Hay, además, ediciones posteriores.

Pedro Sarmiento de Gamboa (1532-1592?) escribió una Historia Indica parcialmente Espasa-Calpe, 1967) que proporciona documentos para la leyenda en el Viejo y Nuevo Mundo. Wilhelm Meyer lo descubrió en la biblioteca de la universidad de Gotinga en 1893. Fue primeramente publicado por Richard Pietschmann con introducción y notas: Pedro Sarmiento de Gamboa, Geschichte der Inkareiches (Abhandlungen der Königlichen Gesellschaft der Wissenschaften $z u$ Göttingen, t. 6, 1902-1906). Traducción inglesa por Clements R. Markham, History of the Incas (Cambridge: The Hakluyt Society, 1907). Hay varias ediciones posteriores del texto español.

Bernabé Cobo (1563-1640) cuando tenìa 15 años vino a América en busca de El Dorado. Llegó a Lima en 1599, y más tarde se convirtió en sacerdote jesuita. Como misionero en distintas partes de Perú (incluyendo lo que es hoy Bolivia) logró un buen conocimiento de las lenguas quechua y aymará. Residió en México de 1630 a 1650 . En el prólogo de su Historia del Nuevo Mundo publicó una historia general de las Indias, pero las partes que han llegado a nosotros tratan especialmente del Perú. El manuscrito sobreviviente, mucho más extenso que las partes que de él se han publicado, fué impreso por Marcos Jiménez de la Espada (Sevilla: Sociedad de Bibliófilos Andaluces, 1890-95). Hay otra edición por Francisco Mateos en la Biblioteca de Autores Españoles, $t$. 91-92 (Madrid: Atlas, 1956). La historia de Cobo, basada en cuidadosas investigaciones, es una mina de información acerca de la sociedad incaica, su cultura y su ambiente natural.

39. Las primeras informaciones acerca de los araucanos de Chile aparecen en las cartas del conquistador Pedro de Valdivia (1497-1553). Cinco cartas de 1545-1552 fueron publicadas primeramente por Claudio Gay en el tomo I de su 
Historia física y política de Chile (Paris: Casa del Autor, 1844-1871). Cinco cartas más fueron encontradas más tarde en diferentes lugares. Edición facsimilar por José Toribio Medina, Cartas de Pedro de Valdivia que tratan del descubrimiento y conquista de Chile (Sevilla: Carmona, 1929), nueva edición por Jaime Eyzaguirre (Santiago de Chile: Fondo Histórico y Bibliográfico José Toribio Medina, 1953) y por Francisco Esteve Barba en Crónicas del Reino de Chile, Biblioteca de Autores Españoles, t. 131 (Madrid: Atlas, 1960). Varias otras crónicas tempranas e historias de Chile contienen información acerca de los araucanos. El gran poema épico La Araucana de Alonso de Ercilla (1533-1594) pretende ser historia verdadera y por mucho tiempo fue la fuente principal que tuvieron los europeos para el conocimiento de Chile, su población y la conquista española. El autor demuestra simpatía por los defensores de la tierra nativa. La primera parte de La Araucana apareció en Madrid, en 1569, reimpresa en Salamanca en 1574, Amberes 1575, y Zaragoza 1577; la segunda parte con la primera, Madrid 1578; la tercera parte, Madrid 1589. La mejor edición es la de José Toribio Medina (Santiago de Chile: Imprenta Elzeviriana, 1910-1918, 5 tomos). Hay muchas reimpresiones populares.

40. La primera gran Historia de las Indias es la de Fray Bartolomé de Las Casas (1474-1566), basada en largos años de experiencia en el Caribe, México, América Central y Venezuela, en muchas conversaciones con parientes de Colón y otras personas importantes asï como en una impresionante cantidad de documentos acumulados a lo largo de su vida. De acuerdo con el plan del autor, debia narrar hechos entre 1492 y 1550 , pero como murió antes de terminar su proyecto sólo cubre los años 1492-1520. El manuscrito de su Historia fue usado por el cronista oficial Antonio de Herrera (1549? -1625). En el siglo XVIII se encontró una copia en limpio que sirvió de base para la primera edición (Madrid: Ginesta, 1875). El manuscrito original utilizado por Antonio Millares Carlo en su edición Historia de las Indias (México: Fondo de Cultura Económica, 1951, 3 tomos). Se ha dicho que la gran pasión de Las Casas como defensor de los indios no perjudicó su juicio como historiador. Se apresuró en publicar sus opúsculos polémicos, pero estableció que su Historia no debía ser enviada a la prensa dentro de los cuarenta años que siguieran a su muerte. (Fue impresa por primera vez 309 años después). Otra importante obra de Las Casas es su Apologética Historia, comenzada como parte de Historia de las Indias. Ha sido considerada uno de los primeros ensayos antropológicos de los indios americanos. Su principal propósito, sin embargo, es probar, como lo haría el abogado, que los indios no son inferiores a los blancos. Fué publicada por Manuel Serrano y Sanz en la "Nueva Biblioteca de Autores Españoles,"' t. 13 (Madrid: Bailly, Baillière, 1909). Esta obra ha sido parcialmente reproducida varias veces, por ejemplo: De las antiguas gentes del Perú, por el Padre fray Bartolomé de Las Casas, edición de Marcos Jiménez de la Espada, Colección de Libros Raros y Curiosos, t. 21 (Madrid: Hernández, 1892), reimpresa y editada por Horacio H. Urteaga (Lima: Gil, 1939). también Fr. Bartolomé de Las Casas, Los indios de México y Nueva España, Antología, editada por Edmundo O'Gorman y Jorge Alberto Manrique (México: Colección "Sepan Cuantos"... No. 57, Editorial Porrúa, 1966). La 
celebridad de Las Casas reside principalmente en su muy controvertida Brevissima relación de la destruyción de las Indias (Sevilla: Sebastián Trugillo, 1552) traducida al holandés (17 ediciones entre 1578 y 1670), al inglés ( 9 ediciones entre 1583 y 1909), al francés (11 ediciones entre 1579 y 1822); además fue traducida a otras lenguas europeas. Ahora disponible en inglés en edición popular: The Devastation of the Indies: A Brief Account, traducida por Herma Briffault, introducción por Hans Magnus Enzesberger (New York: The Seabury Press, 1974). Este pequeño libro que inició la Leyenda Negra continúa agitando a los escritores en acalorados debates en pro y en contra de Las Casas. $\mathrm{Ha}$ sido reimpreso en español pocas veces y fue incluido en la edición de los Tratados de Las Casas (México: Fondo de Cultura Económica, 1965; v. 1, p. 3-199), facsìmil de la primera edición y transcripción del texto español por Juan Pérez de Tudela Bueso.

Gonzalo Fernández de Oviedo (1478-1557) tuvo también conocimiento de primera mano de las Indias Occidentales, pero no compartìa el entusiasmo de Las Casas por los indios. Los primeros 19 libros de su Historia general y natural de las Indias fueron publicados durante su vida (Sevilla: 1535; reimpreso en Salamanca en 1547). Oviedo fue el primer cronista oficial de las Indias cuyas obras han llegado hasta nosotros. El trabajo completo fue publicado con notas por José Amador de los Rios (Madrid: Real Academia de la Historia, 4 tomos 1851-1855) y reimpreso por J. Natalicio González (Asunción del Paraguay: Editorial Guarania, 1945, 14 tomos). Nueva edición por Juan Pérez de Tudela Bueso en la Biblioteca de Autores Españoles, v. 117-121 (Madrid: Atlas, 1959). El Sumario de la Historia Natural de las Indias (Toledo, 1526; muchas reimpresiones modernas) incluye un interesante capitulo de las ceremonias y ritos de los indios de la parte norte de Sudamérica (Tierra Firme). Ver la edición facsimilar en honor de Sterling A. Stoudemire, Natural History of the West Indies (Chapel Hill: University of North Carolina Press, 1959).

41. Francisco López Gómara (1511-1562?) como capellán de Cortés escribió una historia muy legible de la conquista de México, a la cual agregó una larga introducción sobre la historia de las Indias. Estos dos trabajos fueron impresos juntos como Historia de las Indias y conquista de México (Zaragoza, 1552, reimpreso en 1553). Otra edición, con el título de Hispania Victrix fue publicada en Medina del Campo, 1553. Hay muchas ediciones posteriores. Gómara, que representa el punto de vista imperialista, tuvo a su disposición excelentes fuentes y sabia escribir bien, especialmente cuando relata la vida de Cortés. Ver Cortés, The Life of the Conqueror by His Secretary Francisco López de Gómara, traducida y editada por Leslie Byrd Simpson (Berkeley and Los Angeles: University of California Press, 1964; también en edición popular 1966).

El sacerdote jesuita Joseph de Acosta (1540-1600) vivió en Perú (1572-1581) y en México (1586-1587). Su famosa Historia Natural y moral de las Indias (Sevilla: Juan de León, 1590) ha sido reimpresa varias veces, la última por Edmundo O'Gorman (México: Fondo de Cultura Económica, 1940; segunda edición revisada, 1962). Hay traducciones del siglo XVI al italiano, francés, holandés y alemán. Ver la traducción inglesa por E[dward] G[rimston] (Lon- 
don, 1604), The naturall and morall historie of the East and West Indies, (reimpresion: London: The Hakluyt Society, 1880, 2 tomos). El conocimiento de primera mano que de América tenĩa Acosta, su espǐritu inquisitivo y su claro estilo le fueron particularmente útiles al escribir acerca de los aspectos naturales del Nuevo Mundo. Tenía una inclinación filosófica para investigar las causas de los fenómenos pero no fue capaz de llevar su enfoque científico al estudio de la religión de los indios, a las cuales caracteriza como idolatrías. A pesar de sus defectos contiene muchos pasajes valiosos acerca de las sociedades aborígenes de México y Perú en los libros 5 y 6 de Historia. El libro 7 (el último) dedicado a la antigua historia de México, está en su mayor parte transcripto de otra fuente.

Antonio Herrera y Tordesillas (1549-1625) fue nombrado Cronista Mayor de Indias en 1596 y desde entonces coleccionó gran cantidad de documentos. La primera parte de su Historia general de los hechos de los castellanos en las Islas y Tierra Firme del Mar Océano, usualmente llamado Décadas, fue publicado en 1601. Fue seguida por otras partes que cubren todo el periodo de 1492 a 1554. Edición completa por A. Ballesteros y Berreta (Madrid: Academia de la Historia, 1934). Hay otras ediciones. Ha sido traducido a varias lenguas europeas. Existe una traducción del siglo XVIII al inglés por John Stevens: The general history of the vast continent and islands of America commonly call'd, the West Indies, from the first discovery thereof: with the best account the people could give of their antiquities (London: Batley, 1725-1726, 6 vols.). El principal mérito de las Décadas de Herrera reside en el uso de fuentes no publicadas.

42. Una buena selección en español de los cronistas de Indias se encuentra en Luis Nicolau D'Olwer, Cronistas de las culturas precolombinas (México: Fondo de Cultura Económica, 1963). Ver también, Angeles Masiá, Historiadores de Indias, vol. 1, Antillas y Tierra Firme; vol. 2, América del Sur (Barcelona: Editorial Brughera, 1971-1972). La antología de D'Olwer presenta los primeros contactos de los europeos con los indios a lo largo de las Américas. El libro de Masiá sigue un plan diferente pero contiene también muchos textos interesantes sobre las culturas aborígenes en la época de su descubrimiento por los españoles.

Para mayores referencias sobre las fuentes acerca de las sociedades y culturas indigenas a principios de la época colonial, ver Francisco Esteve Barba, Historiografía indiana (Madrid: Editorial Gredos, 1964). Continúa siendo útil, aunque deberìa ser actualizado, el manual de B. Sánchez Alonso, Fuentes de la historia española e hispanoamericana (Madrid: Consejo Superior de Investigaciones Científicas, 3a ed., 1952, 3 vols.) especialmente el tomo I, p. 418-504, y el tomo II, p. 66-127.

43. El manuscrito de Anales de los Cachiqueles ha sido mencionado y usado desde el final del siglo XVII. Habiendo sobrevivido a las guerras de la primera parte del siglo XIX y el caos de las bibliotecas, fue traducido al francés por el Padre Charles Etienne Brasseur de Bourbourg (1814-1874). Juan Gavarrete lo retradujo al español de la versión de Bourbourg y publicado en el Boletín de la Sociedad Económica de Guatemala (1873) como "Memorial de Tecpán Atitlán," tìtulo dado por Brasseur. (Tecpán Atitlán es el nombre náhuatl de la ciudad cakchiquel de Tzololá, moderna Sololá.) Daniel G. Brinton compró 
el manuscrito, lo trasladó al inglés y lo publicó como Annals of the Cakchiquels; luego lo donó a la Universidad de Pennsylvania donde ahora forma parte de la colección Brinton. Ver además Memorial de Sololá. Anales de los Cakchiqueles, edición de Adrián Recinos (México: Fondo de Cultura Económica, 1950).

44. El Título de los Señores de Totonicapán, traducido del texto quiché al español por Dionisio José Chonay, versión inglesa por Delia Goetz, ha sido publicado con los Anales de los Cakchiqueles en la edición mencionada al final de la nota 43. La traducción del Padre Chonay fue realizada en 1834 a pedido de indios del lugar, quienes más tarde hicieron revisar páginas del manuscrito porque, decía, trataban de la creación del mundo, Adán, el Paraiso terrenal y Eva, que en la historia cakchiquel no fue engañada por una serpiente (sin duda un animal sagrado en la mente de los indios) sino por Lucifer como el Angel de la Luz.

45. Ver Adrián Recinos, Crónicas indígenas de Guatemala (Guatemala: Editorial Universitaria, 1957). Esta es una colección de seis textos quiché acompañada de traducciones al español moderno, más la reimpresión de una versión del siglo XVIII de una crónica quiché ahora perdida. Hay otra traducción española antigua de esta crónica (Título de Ixcuin-Nehaib) en la biblioteca del Institute for Advanced Study, Princeton, N. J., algunas páginas de la cual se han perdido.

46. El problema de quién escribió el Popol Vuh ha suscitado una especia de "cuestión homérica" quiché, dando lugar a cantidad de teorias que no es posible exponer aqui. Ver la introducción de Adrián Recinos de su traducción del Popol Vuh (México: Fondo de Cultura Económica, 1947), y René Acuña, "Problemas del Popol Vuh" (Mester, vol. 5, No. 2, abril de 1975, p. 123-134). La tesis de Acuña, de que el Popol Vuh fue escrito por un fraile dominicano español en la primera parte del siglo XVI, no impide la incorporación de muchas fuentes mayas transmitidas por la tradición oral.

47. Hay dos principales enfoques al problema del origen de los mitos: el etnohistórico y el comparativo. No son mutuamente exclusivos sino más bien complementarios. El primero subray a las conexiones entre un mito y la sociedad particular donde es relatado. Si el mismo mito se encuentra entre otras sociedades usualmente se da por supuesto que se trata de un caso de difusión. El problema, se agudiza cuando se hace patente que mitos muy similares, asi como un gran número de motivos míticos, pueden encontrarse por todo el mundo. Aquĩ el segundo enfoque viene a nuestro socorro. Asì como hay estructuras físicas fundamentalmente homogéneas en el género humano independientemente de las diferencias raciales, se postula también una fundamental estructura psiquica uniforme donde se originan muchas imágenes y simbolos primordiales que originan motivos míticos análogos. Esta analogia permite la comparación entre textos y tradiciones ampliamente separados en el tiempo y el espacio. Además de explicar el origen una y otra teorỉa generalmente se relaciona con ideas que pueden contribuir a nuestra comprensión del significado de los mitos. En el primer caso el mito, asĩ como el rito, el lenguaje, las clasificaciones del parentesco, etc., etc., se considera principalmente como una parte de la estruc- 
tura social y debe ser tomado como un aspecto de un sistema más general por medio del cual la naturaleza se transforma en cultura. En el segundo, los mitos son pintorescos mapas verbales, gulas para nuestro inevitable ciclo vital: la áspera y salvaje jungla de la existencia humana se torna una foresta de simbolos que señala el definitivo más allá.

48. Los libros del Chilam Balam fueron conocidos por algunos autores del siglo XVII y XVIII. El libro del Chilam Balam of Chumayel fue parcialmente traducido al español y al inglés en el siglo XIX. La primera traducción española completa fue hecha por Antonio Mediz Bolio, Libro de Chilam Balam de Chumayel (San José, Costa Rica: Lehman, 1930; reimpreso varias veces en la "Biblioteca del Estudiante Universitario" de la Universidad Nacional Autónoma de México con copias de las ilustraciones que fueron omitidas en la primera edición). Primera traducción inglesa del texto completo por Ralph L. Roys, The Book of Chilam Balam of Chumayel (Washington, D.C.: Carnegie Institution, 1933). El libro del Chilam Balam de Tizimin continuaba aún en Yucatán a fines del siglo XIX. Laura Temple lo donó al Museo Nacional de Arqueologia (ahora de Antropologia) en México. Maud Worcester Makenson lo tradujo al inglés como The Book of the Jaguar Priest (New York: Schuman, 1951). El libro del Chilam Balam de Kaua, un volumen de 282 páginas, fue robado de la Biblioteca Cepeda en Mérida, Yucatán, en 1915, y no ha podido ser recobrado, pero hay una copia manuscrita y otra fotográfica. Roys hizo una traducción anotada para el Departamento de Investigaciones Mesoamericanas, de la Universidad de Tulane, y publicó en 1931 algunas recetas médicas contenidas en él. Todavia no se ha impreso ni publicado ninguna edición o traducción completa del libro de Kaua. El libro del Chilam Balam de Ixil, que contiene una farmacopea folklórica, está ahora en la Biblioteca Nacional de Antropologia (Biblioteca de Museo Nacional de Antropología de México). No ha sido nunca traducido o publicado. Una edición facsímil ha sido anunciada por la Akademische Druck- und Verlagsanstalt de Graz, Austria. Del libro del Chilam Balam de Tekax, que tiene solamente 36 páginas, de contenido calendárico y médico, hay una reproducción fotográfica en Middle American Research Institute, Tulane University, pero se desconoce el lugar donde ahora se encuentra el original. William Gates reprodujo el libro del Chilam Balam de Nah (Teabo, Yucatán), trabajo de 64 páginas de las que Roys tradujo los textos médicos (1931). El folleto de 27 páginas titulado "El libro del Chilam Balam" de Tusik (de Tusik, Quintana Roo) ha sido transcripto por Alfredo Barrera Vásquez y parcialmente traducido. Hay una copia fotográfica en la Carnegie Institution, Washington, D.C. pero nunca no ha sido publicado. Pî́o Pérez alrededor de 1840 compiló copias de los libros del Chilam Balam de Maní (hoy perdido), Ixil, y Kaua (mencionados arriba). Esta colección fue llamada Códice Pérez por el erudito obispo yucateco Crescencio Carrillo Ancona. Hay ahora copias en el Museo Nacional de Antropologia (México) y en la Carnegie Institución de Washington. Aparentemente la traducción española de 1949 por Ermilo Solǐa Alcalá de Mérida, Yucatán, permanece todavìa sin publicar. Tomando en consideración el tex to que aparece en más de uno de los libros del Chilam Balam, Alfredo Barrera Vásquez ha hecho una útil traducción 
anotada de los textos del Chilam Balam: El libro de los libros de Chilam Balam (México: Fondo de Cultura Económica, 1948, y reimpresiones económicas). Ver también Alfredo Barrera Vásquez y Sylvanus G. Morley, The Maya Chronicles (Washington: Carnegie Institution, Publicación 585, 1949, p. 1-186.

49. La danza del Tun debe haber sido representada desde los tiempos precoloniales hasta el final del periodo colonial. Probablemente cayó en desuso en la primera parte del siglo XIX, pero fué representada otra vez ante al abate Brasseur de Bourbourg en 1856, quien también consiguió el texto, que tradujo al francés. Publicó el texto y su versión con el título de Rabinal Achí (el guerrero de Rabinal) en un volumen que contiene también su Grammaire de la langue quiché (Paris, Arthus Bertrand, 1862). Georges Raynaud hizo una nueva traducción francesa, que aparentemente continúa inédita pero que fue usada por Luis Cardoza y Aragón para su versión española, "Rabinal Achï, el varón de Rabinal, ballet-drama de los indios quiché de Guatemala" (Anales de la Sociedad de Geografía e Historia, Guatemala, tomo 6, 1929-1930). Esta traducción ha sido reimpresa o adaptada varias veces. Indirectamente es también la base para la versión de Richard E. Leinaweaver, "Rabinal Achi. Commentary and English Translation" (Latin American Theatre Review, 1-2, p. 2-53. Lawrence, Kansas: Center of Latin American Studies, Spring 1968). Ver René Acuña, Introducción al estudio del Rabinal Achí (México: UNAM. Centro de Estudios Mayas, 1975).

50. La palabra 'Güegüence' en apariencia deriva del náhuatl huehue (hombre viejo) $+n$ (eufónica) $+t s z i n$ (sufijo reverencial) $=$ querido hombre viejo. Hay varios manuscritos del drama que se remontan a los tiempos coloniales, acaso no más tarde que el siglo XVIII; algunas versiones han sido coleccionadas en el siglo $\mathrm{XX}$. La primera edición del Güegüence, basada en un texto coleccionado en el siglo XIX por Carl Hermann Berendt, fue cuidada por D. G. Brinton, que le antepuso una introducción e imprimió una traducción libre enfrentando el texto: The Güegüence, a comedy ballet in the Nahuatl Spanish dialect of Nicaragua (Philadelphia: Brinton's Library of Aboriginal American Literature, number 3,1883 ). Hay varias otras ediciones y traducciones. Franco Cerutti imprimió su traducción italiana acompañada por el texto y la traducción al español de Emilio Alvarez L. y la traducción inglesa de Brinton arriba mencionada. Ver el Güegüence, ricostruzione di un dramma balleto del Nicaragua di epoca coloniale (Genova: A.I.S.A., I Quaderni de Terra Ameriga, N. 2, 1968). La edición de Cerutti contiene una útil bibliografỉa. El texto del Güegüence está densamente entre mezclado con palabras y oraciones enteras en español.

51. Ia palabra 'Ollantay' aparentemente es una corrupción de la frase quechua Uil Antay, o Uilla Antay, es decir, la historia (o leyenda) de Los Andes. La primera mención del drama Ollantay fue hecha por Manuel Palacios en su artǐculo "Tradición de la rebelión de Ollantay, y acto heroico de fidelidad de Rumiñahui, ambos generales del tiempo de los incas" (Museo Erudito del Cuzco, Nos 5-9, 1835). El problema de la paternidad literaria de Ollantay ha sido animadamente discutida. Mientras algunos aducen que es puramente india, otros sostienen de que es solamente una versión quechua de una pieza dramática española. Una posición intermedia sugiere que el drama se remonta a los tiempos 
incaicos aunque algunas influencias españolas se han deslizado en los textos recibidos, que pueden ser copias coloniales o traducciones de antiguas versiones. Jacob von Tschudi hizo la traducción al alemán de los textos del manuscrito guardado en el monasterio de Santo Domingo de Cuzco y lo publicó en el tomo II de Die Kechua-Sprache (Vienna: Kaiserlich- königliche Hof- und Staatsdruckerei, 1853). Hay una traducción inglesa por Clements R. Markham, $A n$ Ancient Inca Drama (London: Trubner, 1871), y otra por Abraham Arias Larreta como "Apu Ollantay" en su libro Pre-Columbian Masterpieces (Kansas City: Indoamérica, 1967). Arias Larreta, que favorece la tesis del origen inca del drama, ha discutido extensamente todos estos problemas añadiendo una versión española libre en Literaturas aborígenes de América (Kansas City: Indoamérica, 10a edición, 1976), p. 244-362.

52. Ver J. A. Vázquez, "Nacimiento e infancia de Elal. Mitoanálisis de un texto tehuelche meridional" (Revista Iberoamericana, vol. 42, No. 95, abril-junio de 1976, p. 201-216, nota 1).

53. Una lista de obras aparecidas en los últimos diez años referentes a las modernas tradiciones orales ha sido publicada por Eduardo Lozano en la sección bibliográfica de Latin American Indian Literatures, vol. 1, No. 1, University of Pittsburgh, Spring 1977, p. 41-60.

54. Limitándonos a unos pocos ejemplos, podemos mencionar los siguientes: Rodolfo Lenz, Estudios araucanos (Santiago de Chile: Anales de la Universidad de Chile, 1895-1897), Theodor Koch-Grünberg, Mythen und Legenden der Taulipáng und Arekuná-Indianer, segundo volumen de Vom Roraima zum Orinoko (Berlin: Dietriich Reimer, 1916), traducción al portugués por Henrique Roenick, revisada por M. Cavalcanti Proenza: "Mitos e lendas dos indios Taulipáng e Arekuná," con un prefacio por Alberto Baldus (Revista do Museu Paulista, n.s., vol. 7, 1953; p. 9-202). Fray Cesáreo de Armellada, Taurón Pantón, Cuentos y leyendas de los indios pemón (Caracas: Biblioteca de Cultura, 1964). Del mismo autor Taurón Pemón II, Así dicen los indios (Caracas: Universidad Católica Andrés Bello, 1973). José Marìa Arguedas y Ruth Stephan, The Singing Mountaineers. Songs and Tales of the Quechua People (Austin: The University of Texas Press, 1957). Arabella Wittaker y Viola Warkentin, Chol Texts of the Supernatural (Norman: Summer Institution of Linguistics, 1965). Gerald Weiss, The Cosmology of the Campa of Eastern Peru (Ann Arbor: University Microfilms, 1974; University of Michigan Ph. D. dissertation 1969). Johannes Wilbert, The Folk Literature of the Warao Indians (Los Angeles: UCLA, Latin American Center, 1970). Del mismo autor y editor: Yupa Folktales (1974). André Marcel d'Ans, La verdadera Biblia de los Cashinaua, traducida del francés por Hermis Campodónico (Lima: Mosca Azul, 1975). Jacques Lizot, El hombre de la pantorrilla preñada, traducida del francés por Victor Fuenmayor (Caracas: Fundación de La Salle, 1975).

55. Algunas veces los relatos se cuentan en la lengua aborigen y más tarde son traducidos a una lengua moderna por el mismo relator o algún otro miembro de la tribu quien, a su vez, puede hacer que su versión sea traducida a otra lengua moderna por el etnólogo. Ejemplos: Erland Nordenskiold, An Historical and 
Ethnological Survey of the Cuna Indians, en colaboración con el indio cuna, Rubén Pérez Cantule, a cuidado de Henry Wassén (Göteborg: Göteborg Museum, 1938). Alfred Métraux, Myths of the Toba and Pilagá Indians of the Gran Chaco (Philadelphia: American Folklore Society, 1946). Gerardo Reichel-Dolmatoff, Desana: Simbolismo de los indios tukano del Vaupés (Bogatá: Universidad de los Andes, 1968), traducido por el autor como Amazonian Cosmos: The Sexual and Religious Symbolism of the Tukano Indians (Chicago: The University of Chicago Press, 1971). Por el mismo autor, The Shaman and the Jaguar (Philadelphia: Temple University Press, 1975). Mark Münzel, Erzahlungen der Kamayurá, Alto Xingú, Brasilien (Wiesbaden: Franz Steiner, 1973).

56. Además de colecciones de mitos y cuentos de tribus individuales se han hecho varios ensayos para dar un panorama de las literaturas indigenas de todo un pais. Para Venezuela, por ejemplo, y tenemos: Marǐa Manuela de Cora, Kuai-Maré, Mitos aborigenes de Venezuela (Madrid: Oceánida, 1957) segunda edición: Caracas: Monte Avila, 1975). Lubio Cardozo, Cuentos indígenas venezolanos (Mérida: Universidad de Los Andes, Centro de Investigaciones Literarias, 1968). Fray Cesáreo de Armellada y Carmela Bentivenga de Napolitano, Literaturas indígenas venezolanas, Visión panorámica actual (Caracas: Monte Avila, 1975).

57. Las mejores colecciones de mitologĩa de Sudamérica y de Latinoaméricana son: Theodor Koch-Grünberg, Indianermärchen aus Südamerika (Jena: Eugen Diederich, 1920) que, sin embargo, excluye las civilizaciones andinas; Raffaele Pettazzoni, America Centrale e Meridionale, vol. 4 de su Miti e Leggende (Torino: Unione Tipografico-Editrice Torinese, 1959); Walter Krickeberg, Märchen der Azteken und Inkaperuaner, Maya und Muisca (Düsseldorf: Eugen Diederich, 1968), traducción española y edición por Johanna Faulhaber y Brigitte von Mentz: Mitos y leyendas de los aztecas, incas, mayas y muiscas (México: Fondo de Cultura Económica, 1971). Los libros de KochGrüngerg y Krickeberg se complementan mutuamente. Continúa siendo útil, a pesar de su fecha, Hartley Burr Alexander, Latin American, tomo XI de The Mythology of All Races (Boston: Marshall Jones, 1920, y reimpresiones).

58. Ver por ejemplo Sperata R. de Sauniere, Cuentos populares araucanos $y$ chilenos recogidos de la tradición oral (originalmente en la Revista Chilena de Historia y Geografia, Nos. 21-34, 1916-1918, ahora en forma de libro: Santiago de Chile: Editorial Nascimiento, 1975). José Marĩa Arguedas y Francisco Izquierdo Rios, Mitos, leyendas y cuentos peruanos (Lima: Ministerio de Educación Pública, 1947; segunda edición: Lima: Casa de Cultura de Perú, 1970). Roberto Williams Garcia, Mitos tepehuas (México: Sep-Setentas, 1972). Alejandro Ortiz Rescaniere, De Adaneva a Inkarrí, Una visión indígena del Perú (Lima: Retablo de Papel, 1973).

59. Recientes ejemplos de México: Alain Ichon, La religion des totonaques de la Sierra (Paris: C.N.R.S., 1969), traducción al español por José Arenas, La religión de los totonacas de la Sierra (México: Instituto Nacional Indigenista, 1973). Evon Z. Vogt, Zinacantan, A Maya Community in the Highlands of Chiapas (Cambridge, Mass.: Harvard University Press, 1969). Ver también en 
Handbook of Middle American Indians, editado por Robert Wauchope (vol. 6, editado por Manning Nash, Austin: University of Texas Press, 1967) los siguientes artículos: Munro S. Edmonson, "Narrative Folklore" (357-368), William Madsen, "Religious Syncretism" (369-391), E. Michael Mendelson, "Ritual and Mythology" (392-415). También por Mendelson, Los escándalos de Maximón (Guatemala: Seminario de Integración Social Guatemalteca, 1965) traducido por J. Vielman.

60. Ver Rodolfo Kusch, El pensamiento indígena y popular americano (Puebla: Cajica, 1970).

61. Ver J. A. Vázquez, "Dos cuentos araucanos de Chile" (Ensayos y Estudios, Nos. 2-3, 1973, p. 2-19). La versión inglesa de este trabajo no incluye el texto transcripto de las cintas. Ver "On Araucanian Oral Literature" (Latin American Literary Review, vol. 1, No. 2, Spring 1973, p. 59-63).

62. Ver Mayo Calvo de Guzmán, Leyendas de Calafquén (Santiago de Chile: Arancibia, 1968).

63. Ver Aĭda Cometta Manzoni, El indio en la poesía de América española (Buenos Aires: Joaquin Torres, 1939). Por el mismo autor: El indio en la novela de América (Buenos Aires: Futuro, 1960): Concha Meléndez, La novela indianista en Hispanoamérica (1882-1889) (Rioo Piedras, Universidad de Puerto Rico, 1934). Raymundo Lazo, La novela andina, pasado y futuro (México: Porrúa, 1971). Lancelot Cowie, El indio en la narrativa contemporánea de México y Guatemala (México: Instituto Nacional Indigenista, 1976) contiene extensa bibliografía sobre temas afines, no solamente sobre la novela indígenista en Mèxico y Guatemala.

64. Ernesto Sacoto, El indio en el ensayo de la América española (New York: Las Américas, 1971) se limita a unos pocos clásicos del siglo XIX y sólamente tres ensayistas del siglo XX, muertos hace tiempo: Sarmiento, Montalvo, Martī, González Prada, Vasconcelos, Mariátegui, Reyes). Un enfoque más comprehensivo, que incluyese autores contemporáneos, podria ofrecer una excelente oportunidad para una exploración intelectual.

65. Ver, por ejemplo, Miguel Angel Asturias, Hombres de maíz (Buenos Aires: Losada, 1949; varias reimpresiones), José María Arguedas, Los ríos profundos (Buenos Aires: Losada, 1958 y reimpresiones), Rosario Castellanos, Balún Canán (México: Fondo de Cultura Económica, 1957, y reimpresiones).

66. Entre recientes ensayos mexicanos de esta clase: Gonzalo Aguirre Beltrán y otros, ¿Ha fracasado el indigenismo? (México: Sep-Setentas, 1971). Ver también el prólogo de Aguirre Beltrán a la nueva edición de Alfonso Caso, La comunidad indígena (México: Sep-Setentas, 1971), y los ensayos de Caso en ese volumen. Teoría y práctica de la educación indígena (México: Sep-Setentas, 1973) de Aguirre Beltrán es también oportuno. El movimiento oficial indigenista de México ha sido criticado por Ricardo Pozas A. en su libro Antropología y burocracia indigenista (México: Tlacuilo, 1976).

67. Los ensayos y estudios de las literaturas pensamiento indigenas han subrayado los valores espirituales de las culturas mexicanas aborigenes. Por lo menos dos libros destacados deben mencionarse por su relación con nuestro 
tema: Miguel León-Portilla, La filosofía náhuatl estudiada en sus fuentes (México: Instituto Indigenista Interamericano, 1956; tercera edición, revisada: Universidad Nacional Autónoma, 1966. Traducción inglesa: Aztec Thought and Culture: A Study of the Ancient Nahuatl Mind. Norman: University of Oklahoma Press, 1963), y Laurette Séjourné, Burning Water; Thought and Religion in Ancient Mexico, traducido por Irene Nicholson (London-New York: Thames and Hudson, 1957; reimpreso en Berkeley, California: Shambhala, 1976). La edición en lengua española de este libro fue traducida del manuscrito en francés inédito por Arnaldo Orfila Reynal: Pensamiento y religión en el México antiguo (México: Fondo de Cultura Económica, 1962) que trata de significados metafísicos del simbolismo artǐstico en la clásica civilización de Teotihuacán. Refiriéndose a los campesinos nativos del Perú actual, José Marīa Arguedas ha mostrado la importancia de los valores indígenas para la formación de una cultura nacional. Ver su libro de ensayos, editado por Angel Rama, Formación de una cultura nacional indoamericana (México: Siglo XXI, 1975).

68. Birgitta Leander ha observado que antiguos textos escritos en náhuatl carecen de uniformidad debido a que la lengua de los aztecas nunca fue aceptada y sistematizada como lengua escrita. Ver su libro In xochitl in cuicatl. Flor y canto: la poesía de los aztecas (México: Instituto Nacional Indigenista, 1972), p. 4 , nota 2 . 
